RODRIGO JOSÉ FUZIGER

\title{
AO ARBÍTRIO DE ANANKE: \\ POR UMA REVISÃO DO CONCEITO DE AUTODETERMINAÇÃO NO DIREITO PENAL
}

TESE DE DOUTORADO

Orientadora: Professora Titular Ana Elisa Liberatore Silva Bechara

UNIVERSIDADE DE SÃO PAULO

FACULDADE DE DIREITO

São Paulo 


\section{Ao arbítrio de Ananke: por uma revisão do conceito de autodeterminação no Direito penal}

Tese apresentada como requisito para a obtenção do título de Doutor em Direito Penal

Orientadora: Professora Titular Ana Elisa Liberatore Silva Bechara 
Nome: FUZIGER, Rodrigo José

Título: Ao arbítrio de Ananke: por uma revisão do conceito de autodeterminação no Direito penal

Tese de doutorado apresentada ao Departamento de Direito penal, Criminologia e Medicina forense da Faculdade de Direito da Universidade de São Paulo para a obtenção do título de Doutor em Direito.

APROVADO EM:

\section{BANCA EXAMINADORA}

PRESIDENTE.:

ASSINATURA:

PROF: INSTITUIÇÃO:

JULGAMENTO: ASSINATURA:

PROF.: INSTITUIÇÃO:

JULGAMENTO: ASSINATURA:

PROF.: INSTITUIÇÃO:

JULGAMENTO: ASSINATURA:

PROF.: INSTITUIÇÃO:

JULGAMENTO: ASSINATURA:

PROF.: INSTITUIÇÃO:

JULGAMENTO: ASSINATURA: 
À Professora Ana Elisa Bechara. Espelho e norte em minha trajetória acadêmica $e$ docente. 


\section{AGRADECIMENTOS}

À minha orientadora, Professora Ana Elisa Liberatore Silva Bechara, entusiasta do pensamento livre, que sempre me mostrou que a liberdade das ideias de um jurista deve estar acompanhada do rigor na reflexão e de um olhar contestador diante da realidade.

À Professora Ana Isabel Pérez Cepeda, pelas contribuições ao trabalho, advindas da leitura e sugestões que muito o enriqueceram. Agradeço também pela generosidade quanto às oportunidades acadêmicas a mim proporcionadas.

Aos Professores Augusto Alvino de Sá e Sérgio Salomão Shecaira. Por contribuírem decisivamente (desde os tempos da Graduação) em minha visão de mundo pelo prisma das ciências criminais. Se enveredei para uma carreira acadêmica em Direito penal, é, em grande parte, porque tive professores inspiradores. Agradeço pelas observações feitas à época do exame de qualificação, as quais foram acolhidas na presente tese.

Aos Professores Marcos César Alvarez, João Vergílio Gallerani Cuter, Ana Lúcia Pastore, Ignacio Berdugo Gómez de la Torre, os quais, por variadas formas, contribuíram para a realização dessa tese.

A Othon Maldos. Minha grande inspiração humana, ética e intelectual. Sua visão e incentivo, desde minha infância, culminaram na presente tese.

Aos meus pais, que, com o suor no rosto e mãos calejadas de gente do campo, proveramme de valores indeléveis.

A Zanete, Rose, Paulo e Marcelo, mais do que testemunhas - pois corresponsáveis - em minha trajetória.

A Ohanna Pinheiro e Ana Carolina Silva, pelas leituras atentas empreendidas na versão final da tese.

Aos meus colegas na pós-graduação, destacando-se os queridos Patrick Cacicedo e Bruna Loureiro, pela troca de ideias sobre a pesquisa e pela amizade durante e para além de nossas trajetórias acadêmicas. convívio.

Aos meus amigos na advocacia e docência, pelo constante aprendizado e fraterno

Aos meus alunos, os quais motivam minha busca por constante aprimoramento, buscando contribuir para a formação e visão de mundo de todos eles. Obrigado pela troca de vivências, pelo carinho e pelo entusiasmo. 
FUZIGER, Rodrigo José. Ao arbítrio de Ananke: Por uma revisão do conceito de autodeterminação no Direito penal. 403 páginas. Tese de Doutorado. Faculdade de Direito da Universidade de São Paulo, São Paulo, 2018.

\section{RESUMO}

A presente tese investigará a noção de autodeterminação do sujeito como elemento de sustentação da culpabilidade no Direito penal. A hipótese a ser verificada sugere que o livrearbítrio, verdadeiro alicerce do jus puniendi estatal, é um conceito que não parece apto a fornecer qualquer auxílio na tarefa de (des)legitimar o Direito penal, uma vez que sua comprovação e refutação exorbita o âmbito daquilo que é humanamente cognoscível. Nesse sentido, tem-se por hipótese que o livre-arbítrio funciona como uma presunção essencial à cultura humana, de modo que ele não pode ser afastado sem uma total descaracterização do que se entende como o ser humano e sua sociedade. Diferentemente do inverificável livre-arbítrio e tendo em vista um conceito que pode ser instrumentalizado na tarefa de adequação do Direito penal a uma conformação mínima, propõe-se a adoção da noção de autodeterminação, como um conceito dotado de gradações, uma vez que o sujeito pode ter seu âmbito de autodeterminação restringido em razão de condicionantes físicas, biológicas, sociais. Assim, o indivíduo não é absolutamente livre em suas deliberações e atos, eis que eles dependem das circunstâncias que o permeiam, ou seja, ele é um "ator situado" em um cenário de condicionantes. Interessa ao recorte da pesquisa a influência das ingerências do Estado sobre o sujeito, sendo certo que, em algumas hipóteses de delitos, é legítima a aplicação da ideia de "coculpabilidade", diminuindo a reprovabilidade do indivíduo que cometeu um injusto penal, em virtude de omissões estatais na oferta de bens sociais. Tal medida visa a uma diminuição do cenário de seletividade penal contra as classes subalternas, bem como uma aplicação que melhor se adeque ao princípio da proporcionalidade e a uma perspectiva de Direito penal mínimo.

Palavras-chave: Livre-arbítrio; autodeterminação; culpabilidade; coculpabilidade; seletividade penal. 
FUZIGER, Rodrigo José. By Ananke's Will: For a review of the concept of self-determination in criminal law. 403 pages. Doctorate degree. Faculty of Law, University of São Paulo, São Paulo, 2018.

\begin{abstract}
The present thesis will investigate the notion of self-determination of the subject as a guiding element in criminal law. The hypothesis to be verified suggests that free will, a foundation of the jus puniendi, is a concept that is not able to provide any assistance in the task of legitimize the criminal law, since its proof or refutation exorbit what is humanly knowable. In this sense, it is hypothesized that free will functions as a presumption, which is essential to human culture, so that it can not be removed without a total decharacterization of what is understood as the human being and his society. Unlike the free will, it's proposed the use of a concept that can be instrumented in the mission of adapting criminal law to a minimum range: the selfdetermination, as a concept endowed with gradations, since the subject may have its scope of self-determination restricted due to physical, biological, and social constraints. Thus, the individual is not absolutely free in his deliberations and acts, behold, they depend on the circumstances that pervade him, so, he is an "actor situated" in a setting of constraints. The influence of State interference on the subject is of interest to the research approach, since in some hypotheses it is legitimate to apply the idea of "coculpability", reducing the reproachability of the individual who committed a crime, due to omissions in the supply of social goods. This measure aims at reducing the scenario of criminal selectivity against the subaltern classes, as well as an application that best fits the principle of proportionality and a minimal criminal law perspective.
\end{abstract}

Key words: Free will: self-determination; culpability; coculpability; criminal selectivity. 
FUZIGER, Rodrigo José. Al albedrío de Ananke: Por una revisión del concepto de autodeterminación en el Derecho penal. 403 páginas. Tesis de Doctorado. Facultad de Derecho, Universidad de São Paulo, São Paulo, 2018.

\section{RESUMEN}

La presente tesis investigará la noción de autodeterminación del sujeto como elemento de sustentación de la culpabilidad en el Derecho penal. La hipótesis a ser verificada sugiere que el libre albedrío, verdadero fundamento del jus puniendi estatal, es un concepto que no parece apto a proporcionar ninguna ayuda en la tarea de (des)legitimar el Derecho penal, una vez que su comprobación y refutación exorbita el ámbito de lo que es humanamente cognoscible. En ese sentido, se tiene por hipótesis que el libre albedrío funciona como una presunción esencial a la cultura humana, de modo que no puede ser alejado sin una total descaracterización de lo que se entiende como el ser humano y su sociedad. A diferencia del libre albedrío y teniendo en una vista un concepto que puede ser instrumentalizado en la tarea de adecuación del Derecho penal a una conformación mínima, se propone la adopción de la noción de autodeterminación, como un concepto dotado de gradaciones, pues el sujeto puede tener su ámbito de autodeterminación restringido en razón de condicionantes físicos, biológicos, sociales. Así, el individuo no es absolutamente libre en sus deliberaciones y actos, he aquí que dependen de las circunstancias que lo impregnan, o sea, él es un "actor situado" en un escenario de condicionantes. En el caso de los delitos, es legítimo la aplicación de la idea de "coculpabilidad", disminuyendo el reproche del indivíduo que cometió un injusto penal, en virtud de las omisiones estatales en la oferta de bienes sociales. Esta medida se refiere a una disminución del escenario de selectividad penal contra las clases subalternas, así como una aplicación que mejor se adapte al princípio de proporcionalidad y a una perspectiva del Derecho penal mínimo.

Palabras clave: Libre albedrío; autodeterminación; selectividad criminal; culpabilidad; coculpabilidad; 
"Olhar um átomo modifica-o, olhar um humano transforma-o, olhar o futuro subverte-o."

Gaston Berger ${ }^{1}$

\footnotetext{
${ }^{1}$ BERGER, Gaston. Phénoménologie du temps et prospective. Paris: PUF, 1964, p. 275. (Tradução livre).
} 


\section{SUMÁRIO}

INTRODUÇÃO 14

1 - O LIVRE-ARBÍTRIO COMO PROBLEMA CENTRAL À EXISTÊNCIA HUMANA .28

1.1 - Perspectivas diante do impasse a respeito do livre-arbítrio .34

1.2 - Liberdades e Direito penal. 47

1.3 - Breves considerações acerca das teorias sobre o livre-arbítrio .53

2 - O LIVRE-ARBÍTRIO METAFÍSICO: A LIBERDADE DE AÇÃO COMO PEDRA DE TOQUE DA HISTÓRIA DA FILOSOFIA................................................................62

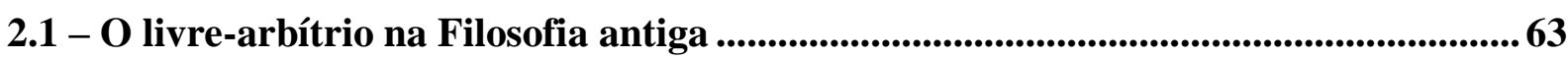

2.1.1 - Aristóteles ...............................................................................................................64 64

2.2 - O livre-arbítrio na Filosofia medieval .................................................................66

2.2.1 - Agostinho de Hipona ........................................................................................66 6

2.3 - O livre-arbítrio na Filosofia moderna ....................................................................................... 70

2.3.1 - Descartes .......................................................................................................... 71

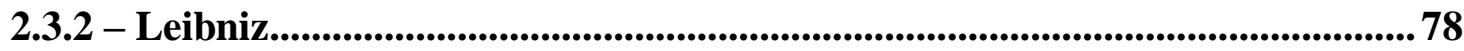

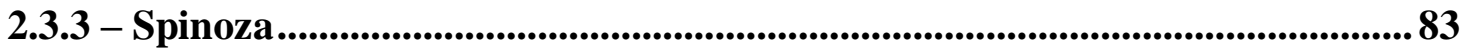

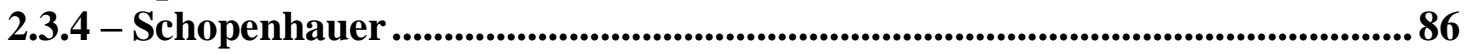

2.4 - O livre-arbítrio na Filosofia contemporânea .................................................................90

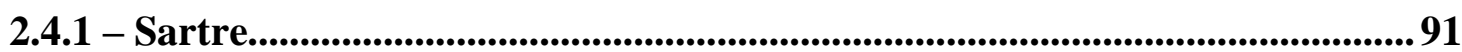

3 - LIVRE-ARBÍTRIO E AUTODETERMINAÇÃO: ALGUMAS PERSPECTIVAS

CIENTÍFICAS ..............................................................................................................98

3.1 - O livre-arbítrio e a Física: acerca da "passagem do tempo" ..................................... 102

3.1.1 - O determinismo da física mecanicista clássica e o resgate do indeterminismo pela física quântica...............................................................................................108

3.2 - O livre-arbítrio e a Biologia: a liberdade é um atributo da vida? ...........................119

3.3 - Neurociência e liberdade de ação ...................................................................................126

3.3.1 - O deslumbramento do Direito penal pela Neurociência ............................... 134

3.3.2 - O impasse persiste: as respostas da Neurociência sobre o livre-arbítrio. 141 3.4 - Para além da Ciência: a "solução" da (não) questão do livre-arbítrio..................... 152

4 - LIVRE-ARBÍTRIO, AUTODETERMINAÇÃO E COMPORTAMENTO SOCIAL 168

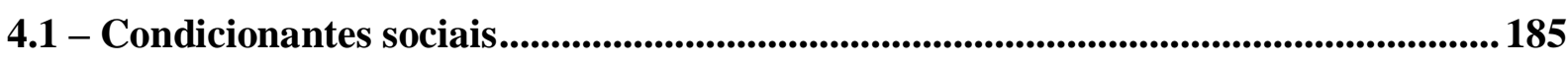

4.1.1 - Atributos morais e expectativas sociais ...................................................... 188

4.2 - A limitação social do plexo de possibilidades individuais............................................. 196

4.3 - A noção de "ator situado": notas a respeito do "cenário" de atuação..................... 202

4.3.1 - Considerações acerca de três modelos de Criminologia Clínica .................205

4.3.2 - Do autor ao ator ..........................................................................................217 
5.1 - Considerações acerca da culpabilidade ...............................................................226

5.1.1 - Culpabilidade ou responsabilidade? .............................................................2234

5.1.2 - O livre-arbítrio (ainda) é o alicerce da culpabilidade? ................................243

5.1.3 - É possível conceber um Direito penal sem culpabilidade? ......................... 255

5.2 - A coculpabilidade: um prelúdio teórico ...................................................................... 263

5.2.1 - A "culpabilidade por vulnerabilidade" .........................................................278

5.2.2 - Cotejando "coculpabilidade" e "culpabilidade por vulnerabilidade" .....283

6 - AUTODETERMINAÇÃO, O ATOR SITUADO E A COCULPABILIDADE ........296

6.1 - Quando o Estado situa o ator ..................................................................................304

6.1.1 - Estigmatização e autodeterminação ..................................................................309

6.1.2 - Breve crítica a uma conclusão do paradigma da reação social: a ausência de ontologia do crime...................................................................................................................... 311

6.2 - O legislador e o julgador como atores situados ................................................................ 316

6.3 - Porque, como e onde situar a coculpabilidade no Direito penal brasileiro..............320

6.3.1 - A previsão da coculpabilidade no ordenamento de outros países ............. 330

6.3.2 - A inserção da coculpabilidade no ordenamento brasileiro ........................335

6.3.2 - Proposta de positivação da coculpabilidade no Código penal brasileiro. 347

6.4 - Proporcionalidade e seletividade ..................................................................................... 357

6.5 - Operando com a (im)popularidade do Direito penal ...............................................364

6.5.2 - Limitando um instrumento limitado.................................................................. 368

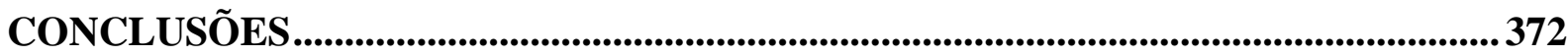

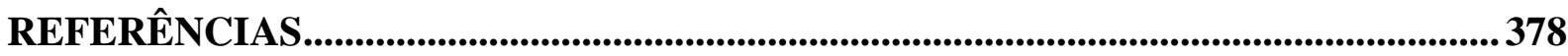




\section{INTRODUÇÃO}

"A doutrina da liberdade humana fornece a prova de que, às vezes, uma hipótese errônea é preferível a uma hipótese exata"². O provocativo aforismo de Georg Christoph LICHTENBERG aponta para uma insustentável aporia que tem sido objeto primordial no pensamento de diversos autores, de variadas áreas, há milênios: a liberdade ou ausência dela nas ações humanas, ou seja, se realmente somos de fato libertos das amarras de relações de causalidade perpetradas em um trajeto que ruma ad infinitum.

Tal pergunta - vital à Teologia e à Filosofia, mas que também acabou por enveredarse pelos mais diversos campos do conhecimento - permanece sem uma resposta inequívoca ou, ao menos segura, embora, cada vez mais, Física, Psicologia e Neurociência têm desconstruído o paradigma de liberdade de ação que sustenta as relações sociais.

Diante das constatações cada vez mais sólidas de tais ciências, o excerto inicial aponta para uma constatação: mesmo que, faticamente, inexista liberdade em nosso comportamento e nossa concepção de livre-arbítrio seja um colossal mal-entendido ou uma necessidade de primeira grandeza - não mais parece ser possível abdicar-se de tal hipótese. O despertar desse suposto estado ficcional representaria a falência inelutável de toda essa construção coletiva denominada humanidade, que, sem o livre-arbítrio, nada mais seria do que um conjunto de autômatos conduzidos por inexoráveis relações causais pré-estabelecidas.

Desta feita, ficcional ou não, a ideia de livre-arbítrio é um atributo essencial à sociedade. Portanto, como bem aponta Georg LICHTENBERG, a hipótese que apregoa a existência do livre-arbítrio, ainda que errônea, é inafastável à conformação de toda e qualquer sociedade. Assim, para o bem e para o mal, o indivíduo é considerado senhor de seus atos e responsabilizado na medida de sua conduta.

Essa estrutura é a tônica do funcionamento social, sendo, obviamente, também reproduzida dentro do prisma do Direito penal, objeto central da tese. Conquanto tal ramo do Direito possua idiossincrasias no que concerne à atribuição de responsabilidade, é inegável que a pedra fundamental da penalização seja a ideia de que o ser humano (sendo e estando imputável no momento da conduta e ciente desta) pode ser responsabilizado por ter se comportado de

\footnotetext{
${ }^{2}$ LICHTENBERG, Georg Christoph. Aphorismes. Tradução de Marthe Robert. Paris: J. J. Pauvert, 1966, p. 105.
} 
forma ilícita, quando poderia e deveria ter agido de maneira distinta. Trata-se, portanto, de um plexo de escolhas possíveis ao indivíduo, que dentre elas optou (e tal verbo denota e pressupõe liberdade) por uma dessas condutas possíveis, sendo tal conduta eleita tipificada como ilícita e, mais do que isso, como criminosa.

A primeira indagação acerca da utilização do livre-arbítrio como expediente legitimador do Direito penal é a respeito da própria existência dessa suposta liberdade. Há correntes que apontam para tanto, sendo a defesa do livre-arbítrio a posição proeminente sobre o tema, desde a chamada Escola Clássica do Direito penal.

Por outro lado, há correntes de pensamento que colocam sob dúvidas e até mesmo refutam o livre-arbítrio. Nesse sentido, imagine-se uma realidade em que essa noção de liberdade seja colocada em suspensão: lançando mão da mecânica acima esboçada do funcionamento do Direito penal, não faria qualquer sentido pensar nem mesmo em uma preocupação acerca da penalização ou não das condutas tidas como ilícitas.

Isso porque as condutas foram tipificadas em virtude de uma cadeia de fatores sucessivos além do controle da humanidade; a conduta criminosa também adveio de uma inelutável cadeia causal; por sua vez, a própria preocupação coletiva acerca da penalização seria um sentimento derivado de cadeias causais pré-estabelecidas e a penalização ou não decorreria, por seu turno, de uma sucessão não modificável de acontecimentos, ou seja, a própria percepção de possibilidades (de que o indivíduo poderia ser ou não punido) já era algo pertencente a uma cadeia causal determinada de antemão.

No pavoroso (embora plausível aos olhos de alguns filósofos e cientistas) cenário de impotência acima descortinado uma postura possível (conclusão, diga-se de passagem, que já seria pré-estabelecida, portanto, sem qualquer liberdade) seria a da indiferença. Atributos como mérito e culpa perdem razão de ser em um mundo que se prostra diante do implacável destino previamente estabelecido, da ausência de opção e de possibilidades. Tal panorama estaria bem sintetizado na expressão árabe maktub, traduzível como "estava escrito".

Em prol da vida em sociedade e ainda que uma ficção, há que se crer no livre-arbítrio, não apenas como fundamento do Direito penal $^{3}$, mas de toda humanidade nos seus mais

\footnotetext{
${ }^{3}$ HASSEMER aponta que a certeza de que podemos agir de outro modo é uma mentira vital, mentira em que os penalistas são os primeiros a crer. Cf. HASSEMER, Winfried. Neurociencias y culpabilidad en Derecho penal. Tradução de Manuel Cancio Meliá. In: Indret - Revista para el análisis del derecho, Barcelona, $\mathrm{n}^{\circ}$ 2, 2011, p. 10.
} 
diversos âmbitos. Essa imprescindível crença leva a um segundo e duplo questionamento (rememorando-se que a primeira questão versava sobre a existência do livre-arbítrio): por que o livre-arbítrio é um imperativo ao ser humano e sobre que tipo de raciocínio está fundada tal noção de liberdade?

Face a esta dupla indagação, constrói-se toda argumentação, já aqui brevemente esboçada, que justifica a premente necessidade de concepção do humano como ser livre. Tal premissa, no entanto, depende de um alicerce a seu respeito, que se apresenta de variadas formas: o livre-arbítrio é uma constatação metafísica; o livre-arbítrio é uma constatação fundamentada cientificamente; o livre-arbítrio - numa posição "agnóstica" acerca de sua existência - é uma presunção teleologicamente orientada; o livre-arbítrio é um fato com status de premissa, sob uma abordagem do materialismo-histórico; o livre-arbítrio é uma ficção utilitarista, fisicamente refutável, mas metafisicamente necessária à humanidade; dentre outras possíveis teses acerca do porquê e como se fundamenta o livre-arbítrio.

Há ainda uma terceira questão, absolutamente central ao presente trabalho: até que ponto o ser humano é livre. Assim, diante de uma presunção que parte de uma situação de liberdade de agir, que situações contingentes estão aptas a restringir o indivíduo ao ponto de suprimir sua condição de comportamento plural, ou seja, de agir a partir de um espectro de liberdade que o faça poder eleger, por exemplo, entre o que é lícito e ilícito.

Nesse sentido, se a presunção acerca do livre-arbítrio parece ser uma condição inelutável, cabe perquirir se a partir do pressuposto de liberdade o sujeito pode de fato determinar-se de acordo com sua vontade e consciência, ou seja, autodeterminar-se, tendo domínio causal de suas condutas, a partir de suas vontades, ainda que elas estejam condicionadas em maior ou menor grau por uma série de circunstâncias fáticas.

No exame dessa causalidade relacionando vontade e conduta, há o risco de se cair no hermético discurso científico que aproxima o desviado do inimputável, o que em nada resolve a dilema do sistema punitivo, já que, notadamente, tal solução apenas substitui pena por medida de segurança. Por isso, a solução à questão do livre-arbítrio em relação à culpabilidade parece menos estar dentro do âmbito da "imputabilidade" e mais dentro de um novo delineamento ou expansão dos modelos de culpabilidade. 
Nesse sentido, é imperioso que o delineamento da culpabilidade, como elemento do delito, seja apto a albergar as condutas praticadas dentro de um reduzido âmbito de discricionariedade, advindas de situações "condicionantes", ou seja, que induziriam decididamente a atuação do agente. Nesse sentido, em certos cenários, circunstâncias sociais poderiam limitar o plexo de possibilidades de ação de um sujeito, reduzindo sua capacidade de autodeterminação dentro dos parâmetros lícitos.

Em outras palavras, embora as expectativas sociais sejam comungadas coletivamente (por exemplo, êxito financeiro, notoriedade, dentre outras metas generalistas) para determinados sujeitos, o alcance de tais objetivos por trajetórias lícitas é sobremaneira difícil. Há um ponto de chegada homogêneo com pontos de partida absolutamente heterogêneos.

Mais além, em um sem número de casos criminais, nota-se que o infrator careceu daquilo que é mais comezinho em termos de direitos assegurados a qualquer ser humano, privado de bens sociais em um patamar aquém do que se entende como o mínimo existencial a qualquer indivíduo. Há que indagar-se, em situações como essas, se a autodeterminação do sujeito não sofreu limitações decisivas à opção para a trajetória criminal.

Tais possibilidades poderiam aportar soluções normativas de racionalização do Direito penal, frente a situações concretas em que indivíduos imputáveis, conscientes da ilicitude do fato e com possibilidade de comportamento diversos cometem crimes, por estarem inseridos em uma situação de autodeterminação restringida por corriqueiras limitações de ordem social. Se, a princípio, tal hipótese possa soar laxista aos ouvidos da sociedade (condicionada por discursos rigoristas), de outra mão, ela tem o mérito de atribuir um novo critério de aplicação proporcional do Direito penal.

Há, no entanto, uma aporia decorrente da análise do livre-arbítrio e culpabilidade, sobretudo no específico aspecto do nexo de causalidade motivador do ilícito, diz respeito ao solipsismo inerente a cada comportamento individual, dificultando o processo de generalização necessário para a criação de padrões normativos que orientem minimamente a discricionariedade do julgador.

Ao que parece, como hipótese resolutiva desse impasse acerca do acesso à subjetividade dos indivíduos, é necessário trabalhar dentro do plano da presunção. Nesse sentido, se a própria ideia de livre-arbítrio, fundamentadora da punição pelo direito penal, é uma presunção, não há que se falar em empecilho dogmático ao se inserir dentro do Direito penal uma presunção 
limitadora de sua incidência, que levasse em consideração que em determinadas situações, objetivamente verificáveis, o indivíduo encontra-se em uma situação de debilidade em sua autodeterminação.

A culpabilidade parte do pressuposto da liberdade de decisão, amparada pela consciência e voluntariedade de um comportamento. Se assim o é, talvez seja fundamental inserir elementos que mitiguem o alcance de tal normatização do comportamento, por meio de variáveis também normativas, que não digam respeito à existência ou não de liberdade comportamental, mas sim de limitações ou supressão da premissa (possivelmente fíctícia) de que possuímos plena autodeterminação.

Para tanto, dois conceitos - com origens, fundamentações e autorias distintas - serão cotejados em busca da verificação da hipótese apresentada, quais sejam, o do "ator situado" e o da "coculpabilidade".

O primeiro conceito é o de "ator situado", do criminólogo belga Christian DEBUYST, segundo o qual o sujeito deve ser enxergado a partir de uma síntese do pensamento racional (em que o indivíduo é dotado de escolha livre e racional) e do pensamento determinista (que idealiza o indivíduo como condicionado em suas ações). A partir da simbiose dessas duas ideias, o autor é muito mais um ator (acteur), uma vez que atua dentro de um cenário repleto de condicionantes (posição social, biografia, modo de vida) que influenciam suas tomadas de decisão e seus comportamentos.

O segundo conceito é o da "coculpabilidade", da lavra do jurista argentino, Eugenio Raúl ZAFFARONI, que concebe a coculpabilidade como uma valoração da atuação estatal (suas ações e omissões) em relação ao criminoso, procurando avaliar se de alguma forma o Estado contribuiu para o comportamento delitivo do sujeito. Evidentemente, em caso afirmativo, o Estado não seria punido como coautor ou partícipe na empreitada criminosa. A coculpabilidade serviria como um elemento limitador do jus puniendi estatal justamente em razão de uma atuação deficitária ou ilegítima sobre a biografia do indivíduo. Expõem ZAFFARONI e PIERANGELI:

Todo sujeito age numa circunstância dada e com um âmbito de autodeterminação também dado. Em sua própria personalidade há uma contribuição para esse âmbito de autodeterminação, posto que a sociedade por melhor organizada que seja - nunca tem a possibilidade de brindar a todos os homens com as mesmas oportunidades. Em consequência há sujeitos que 
têm um menor âmbito de autodeterminação, condicionado desta maneira por causas sociais. Não será possível atribuir estas causas sociais ao sujeito e sobrecarregá-lo com elas no momento da reprovação de culpabilidade. ${ }^{4}$

Nesse sentido, conjugando os conceitos esboçados, se os indivíduos são "atores situados" em uma determinada realidade na sociedade, há sobre eles a influência das ingerências do Estado, como um dos principais colaboradores na tarefa de construir um cenário social. Ou seja, o ator está situado em um palco cuja construção tem enorme contribuição da atuação estatal. O Estado, portanto, pode ser decisivo no comportamento individual, inclusive no comportamento criminoso.

A coculpabilidade busca situar a análise da culpabilidade dentro de um patamar de proporcionalidade, a partir dos limites da autodeterminação do sujeito, levando em consideração as possibilidades a ele oferecidas em cotejo com as expectativas que a sociedade (em certa medida condicionadas pelo próprio Estado) deposita sobre cada individualidade.

Por fim, necessário justificar a escolha do título da tese, qual seja, “Ao arbítrio de Ananke: por uma revisão do conceito de autodeterminação no Direito penal”. Para mais além do que uma mera marca de estilo na escrita, recorre-se à mitologia como forma de metaforizar o milenar impasse do ser humano diante do livre-arbítrio.

Ananke é uma divindade primeva na teogonia grega (chamada de Necessitas na mitologia romana, decorrendo daí a etimologia de necessidade, com o sentido de algo inexorável). Trata-se da deusa do destino, da inevitabilidade, da necessidade (no sentido filosófico do termo). ${ }^{5}$ Não há como se escapar dos desígnios de Ananke, os quais regem todo o universo, suas criaturas e, na mitologia grega, até mesmo os deuses olímpicos. ${ }^{6}$

\footnotetext{
${ }^{4}$ ZAFFARONI, Eugenio Raul e PIERANGELI, José Henrique. Manual de Direito Penal Brasileiro. Parte Geral. 5a ed., São Paulo: Revista dos Tribunais, 2004, p. 613.

${ }^{5}$ SMITH, William. A new classical dictionary of Greek and Roman Biography, Mythology and Geography. Nova Iorque: Harper \& Brothers, 1984. P. 523.

${ }^{6}$ No diálogo Protágoras, Platão recorre ao poeta Simonides ao afirmar que nem mesmo os Deuses podem lutar contra Ananke.
} 


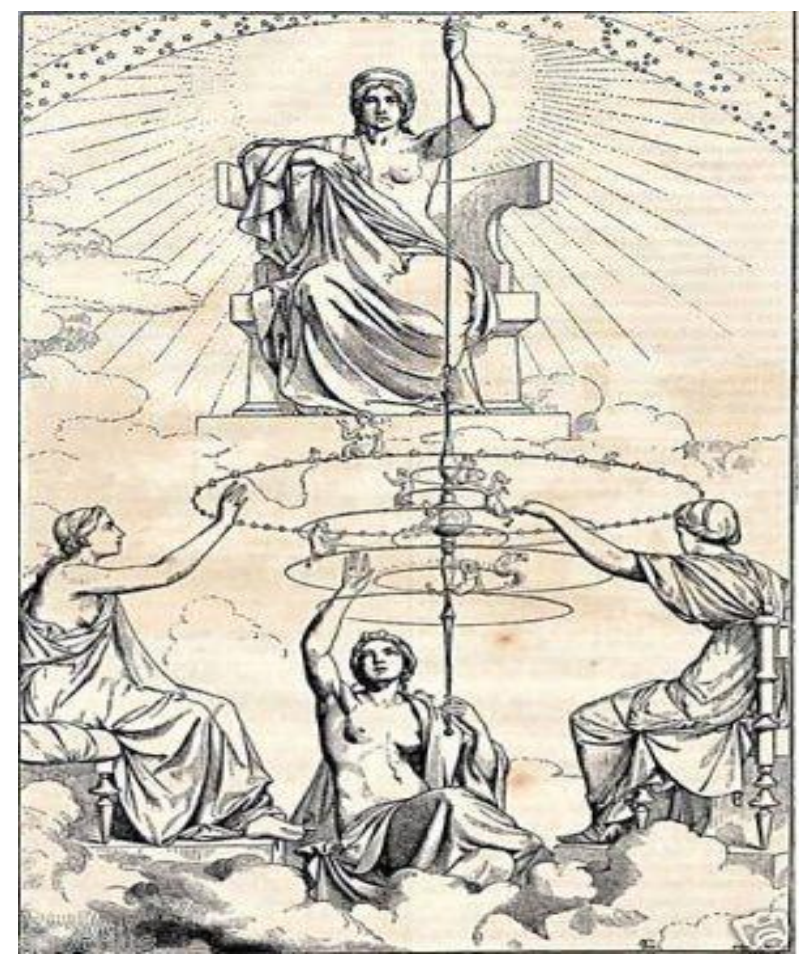

Representação (em uma edição ilustrada da República, de Platão) de Ananke com suas três filhas, as Moiras: Cloto, Láquesis, Átropos

Ananke, consorte de Khronos (o Deus-tempo) costuma ser representada junto de suas filhas (as Moiras: Clotos, Láquesis e Ártropos) portando um fuso ${ }^{7}$, do qual saem os fios da vida de todos os humanos (fios que são trabalhados pelas Moiras), os quais são regidos pelas regras universais e necessárias de Ananke.

O mito de Ananke sinaliza para a curiosa crença dos gregos antigos segundo a qual a ideia de livre-arbítrio não era plenamente acessível aos homens, tampouco aos deuses, mas sim apenas à própria divindade regente do destino, cuja inevitabilidade foi tão bem explorada em tragédias gregas, como “Édipo Rei”, de Sófocles.

Ainda em veredas literárias, porém mais de dois milênios após Sófocles, a pena de Victor Hugo cuidou de Ananke, em uma breve passagem que inicia a obra Les travailleurs de la mer. É justamente tal excerto (talvez por uma vontade de Ananke...) que motivou a metáfora

\footnotetext{
${ }^{7}$ No livro X da República de Platão, ao narrar o Mito de Er, o filósofo grego menciona Ananke e seu "fuso da necessidade".
} 
que intitula a presente tese. Nele, Victor Hugo afirma: "Uma tripla Ananke repousa sobre nós, a Ananke dos dogmas, a Ananke das leis e a Ananke das coisas."

O objetivo da investigação será justamente buscar essa "Ananke multifacetada”, ou seja, os elementos que restringem a autodeterminação humana, sejam eles físicos, biológicos, sociais ou, mais especificamente, jurídicos, avaliando quais deles são aptos a uma instrumentalização que colabore para o processo de contenção do Direito penal.

Nesse sentido, embora não seja possível abdicar da presunção de livre-arbítrio, não se mostra adequada a extrapolação de tal presunção, de modo a considerar que todos também possuem plena autodeterminação. Há que se verificar se a autodeterminação pode ser graduada a partir da situação de cada ator social e, ainda, se é adequado operar no Direito penal com um princípio da culpabilidade que não parece levar em conta as possíveis restrições das possibilidades de cada sujeito.

O interesse na temática advém da incipiente exploração pela doutrina brasileira do assunto, bem como das novas aproximações que a ciência oferece em relação à capacidade de determinação do ser humano e de que forma isso pode reverberar dentro da noção de culpabilidade dentro do Direito penal. Nesse sentido, por exemplo, as novas descobertas da Neurociência supostamente relativizariam cada vez mais a noção de livre-arbítrio, atribuindo uma condição de assujeitamento do humano a processos inconscientes que antecipam decisões tidas como "livres e racionais".

Assim, falar do progresso científico no Direito penal - em um recorte da concepção do livre-arbítrio para a Neurociência ou mesmo à Física (em releituras da Teoria da Relatividade) - significa reacender o debate acerca da apropriação dos discursos da ciência, como saberes que se tornam poderes, ou seja, na validação e justificação da coercibilidade estatal (cujo paroxismo é atingido por meio do Direito penal) mediante argumentos científicos, os quais, são inexoravelmente dotados de falibilidade e, mais além, necessitam de uma crivagem crítica.

A Filosofia adquire papel de protagonista nesse panorama de crítica, em virtude de uma de suas indagações mais basilares ser justamente a questão do livre-arbítrio. E, mais ainda, é fundamental lançar um olhar filosófico sobre as implicações de alicerçarmos todo nosso aparato social (e, portanto, penal), sob uma presunção: a de que nós possuímos, de fato, livre-

\footnotetext{
${ }^{8}$ HUGO, Victor-Marie. Les travailleurs de la mer. Paris: Gallimard, 1980, p 4.
} 
arbítrio ou, ainda, de que além do livre-arbítrio possuímos plena autodeterminação. Nesse sentido, adentrando-se à seara do Direito penal, há que se esmiuçar especificamente todas as implicações da relação (problemática, posto que necessária) entre ficção (presunção de liberdade) e culpabilidade.

O recorte temático foi elaborado visando a centrar a investigação sobre o Direito penal no restrito âmbito do conceito de culpabilidade e sua fundamentação na liberdade de ação do sujeito, a priori, a partir de uma desconstrução do livre-arbítrio no Direito penal e, posteriormente, empreendendo uma releitura da configuração da autodeterminação do sujeito dentro do prisma da culpabilidade jurídico-penal.

Assim, não obstante esteja fora de cogitação para a cultura humana prostrar-se diante do argumento determinista - segundo o qual não existe qualquer liberdade comportamental - é fundamental encontrar um "ponto ótimo" a respeito da autodeterminação, que não tangencie demasiadamente a noção simétrica do determinismo, ou seja, um irrestrito livre-arbítrio, aos moldes da Filosofia medievalista. Em outras palavras, se os humanos são livres (ainda que à força de uma presunção), que seja levada em consideração a possibilidade de que não são tão livres assim, investigando-se quais condicionantes atuam sobre a autodeterminação dos sujeitos.

Com vistas a introduzir o percurso que será empreendido na presente tese, os parágrafos a seguir conterão esboços dos temas que serão abordados em cada um dos capítulos que compõem o trabalho.

O capítulo "1 - O livre-arbítrio como problema central à existência humana" buscar-seá descortinar a problemática que gira em torno da liberdade de vontade e ação do ser humano, demonstrando como a (in)existência do livre-arbítrio é uma das questões mais tormentosas da história do pensamento humano, eis que desde tempos imemoriais, toda a gramática das relações humanas é construída a partir da crença na liberdade de agir de si e do outro, o que permite a elaboração de prêmios e punições aos indivíduos, a depender de seu comportamento, valorado como meritório ou demeritório. Tal mirada só é possível a partir da premissa de que o comportamento avaliado foi realizado a partir da vontade do sujeito, pois sem esse atributo não faz sentido afirmar que o indivíduo agiu com culpa ou mérito ao externalizar determinada conduta. 
Em tal capítulo serão lançadas luzes sobre a ideia de liberdade, termo notadamente polissêmico, sendo que seu significado abstratamente múltiplo deve ser contextualizado para a real compreensão de que sentido de liberdade está a se falar. Isso porque, mesmo no restrito campo do Direito penal, o vocábulo liberdade possui uma miríade de significados. Apenas como exemplos dos sentidos possíveis, "liberdade" é um bem jurídico tutelado pelo Direito penal e, concomitantemente, também é um bem jurídico restringido por meio da pena de prisão.

Ao fim desse capítulo inicial, será esboçada uma síntese das principais posições relacionadas à (in)existência do livre-arbítrio: o determinismo, o indeterminismo e também posições compatibilistas, as quais possuem diversas matizes e, guardadas as peculiaridades de cada uma, defendem a possibilidade do livre-arbítrio coexistir com um mundo determinado, ou seja, regido por relações causais.

O capítulo " 2 - O livre-arbítrio metafísico: a liberdade de ação como pedra de toque da história da Filosofia" incursionará pelo intrincado e milenar debate filosófico a respeito do livre-arbítrio, uma vez que se trata de um dos temas mais debatidos e importantes da tradição filosófica. Conforme será evidenciado ao longo do texto, por ser o livre-arbítrio um tema filosófico por excelência e em virtude da dogmática penal ser profundamente influenciada por aportes filosóficos, optou-se por iniciar o alicerce teórico do debate a respeito da liberdade humana, a partir da Filosofia e, sempre que adequado, relacionar os pensamentos dos filósofos escolhidos com aspectos da dinâmica do Direito penal contemporâneo.

Muito filósofos deitaram o olhar sobre o assunto, derivando disso diversas teorias que defendem ou refutam o a liberdade de ação do homem. Evidentemente, tentar catalogar e colacionar toda produção filosófica a respeito do livre-arbítrio é uma tarefa sobre-humana e totalmente alheia ao recorte dessa tese. Dessa forma, importantes pensadores que abordaram o tema do livre-arbítrio não foram analisados. Optou-se, com a intenção de evidenciar a trajetória do pensamento humano (em um recorte da tradição filosófica ocidental), por uma abordagem que selecionou cronologicamente alguns dos principais filósofos da história da humanidade e que trataram diretamente da temática em suas obras.

Como dito, o percurso que aqui aborda o livre-arbítrio na Filosofia buscou seguir um norte cronológico, lançando mão da tradicional divisão do estudo da história da Filosofia ocidental, dividida em quatro períodos, quais sejam, o antigo, o medieval, o moderno e o contemporâneo. Há, nesse sentido, a análise da visão acerca do livre-arbítrio de autores de cada 
um desses períodos. No entanto, não há uma divisão exata entre número de autores, prevalecendo uma quantidade maior de filósofos que correspondem ao período moderno. Tratase de uma escolha deliberada, pois, entende-se que nesse momento o assunto alcançou patamares notáveis, surgindo, a partir dessa ebulição do debate sobre o tema, diversas e complexas teorias filosóficas, algumas das quais serão abordadas no capítulo em questão.

Posteriormente, o capítulo "3 - Livre-arbítrio e autodeterminação: algumas perspectivas científicas" abordará algumas aproximações empreendidas entre Ciência e livre-arbítrio. É notável pluralidade de perspectivas científicas que ao menos tangenciam o tema da liberdade humana. Tal qual justificou-se acima em relação à Filosofia, seria impossível elaborar um compêndio que relacionasse Ciência e livre-arbítrio.

Ainda que o fosse, não seria um recorte apropriado a uma tese de Direito penal, este que é justamente o elemento decisivo na escolha a respeito de quais abordagens científicas estariam presentes nesse trabalho. Isso porque a opção por influxos da Física, da Biologia e, destacadamente, da Neurociência decorrem de aproximações outrora realizadas por juristas brasileiros e estrangeiros, relacionando tais ciências e o Direito, inclusive discorrendo sobre os aportes de tais ramos científicos sobre o debate jurídico a respeito do livre-arbítrio, este que é elemento fundante na estruturação do Direito.

Assim, inicialmente serão analisadas algumas considerações da Física sobre o dilema da liberdade de agir do ser humano, primeiro a partir da ótica da Física clássica mecanicista (determinista) e, após, sob o prisma da Física quântica, a qual rompe com a tradição determinista. Todavia, caberá avaliar se tal rompimento assegura a existência do livre-arbítrio, é dizer, se as constatações da Física quântica de fato reverberaram sobre a noção de liberdade de ação do homem.

Posteriormente, será realizada uma aproximação entre a Biologia e o livre-arbítrio, a partir de uma reflexão acerca deste ser um atributo relativo à vida. Se não o for, cabe perquirir que condições e peculiaridades a vida humana apresenta para supostamente possuir tal atributo.

Ao cabo desse capítulo, restará seu ponto central, o cotejo entre os influxos neurocientíficos e o Direito penal. É inconteste que a Neurociência virou um tema de ressalto dentro da doutrina penal, sobretudo em razão de certos estudos que supostamente relativizariam a noção de culpabilidade do sujeito e mesmo a possibilidade de existência do que é entendido como livre-arbítrio. Se tais estudos estiverem corretos e de fato puderem refutar o livre-arbítrio, 
inegavelmente, cai por terra toda estruturação do Direito penal moderno, lastreado na responsabilização subjetiva do indivíduo.

Todavia, conforme será explicitado, tem-se por hipótese que todos os estudos neurocientíficos estão metodologicamente corretos e de fato criam novas verdades, no entanto, verdades científicas, as quais não são aptas a modificar um conceito como o livre-arbítrio, eminentemente construída a partir da percepção e experiência compartilhada socialmente de liberdade de agir. Assim, tal capítulo será finalizado com uma reflexão da noção de livrearbítrio a partir da Filosofia da linguagem, de modo a contrapor as afirmações de alguns neurocientistas que, com base nos resultados de experimentos realizados nas últimas décadas, fortaleceram as fileiras da corrente determinista.

No capítulo “4 - Livre-arbítrio, autodeterminação e comportamento social”, adentrarse-á em uma nova perspectiva acerca da liberdade de agir do ser humano. Em virtude da incognoscibilidade da (in)existência do livre-arbítrio (tema que não permite uma incontestável comprovação ou refutação), propõe-se uma mirada em um novo conceito (relacionado, embora distinto do livre-arbítrio), a autodeterminação. Não à toa, o título do trabalho menciona uma revisão de tal conceito, haja vista ser ele costumeiramente compreendido como sinônimo de livre-arbítrio.

Dessa forma, o debate sai de uma insuperável aporia (a verificação do livre-arbítrio), uma vez que a liberdade de agir do ser humano passa a funcionar como uma presunção, alicerçada em dados da experiência (na ideia de perceber a si e aos demais como livres). Todavia, ainda que supostamente livre, é cediço que a depender das circunstâncias a liberdade de decisão encontra maior ou menores opções. Assim, ainda que livre, os seres humanos possuem plexos de possibilidades distintos, titularizando, portanto, mais ou menos autodeterminação em um determinado contexto situado no espaço-tempo.

A autodeterminação não é absoluta, mas sim matizada, variando em virtude de elementos físicos, biológicos e sociológicos. Interessa ao recorte da tese, como será explicitado em tal capítulo, a análise das condicionantes sociais que interferem na liberdade de ação dos indivíduos.

O capítulo "5 - Livre-arbítrio, autodeterminação e Direito penal" alcança o cerne da presente tese, a aproximação dos conceitos de livre-arbítrio e autodeterminação ao universo do Direito penal. Em tal capítulo, será realizado um percurso sobre a complexa categoria da 
culpabilidade jurídico-penal, sem qualquer pretensão de um estudo histórico do desenvolvimento de tal instituto, tampouco a intenção de esgotar as diversas teorias a respeito da culpabilidade que foram concebidas ao longo do pensamento jurídico-penal.

Interessa a tal capítulo contextualizar a ideia de culpabilidade e de que forma ela está associada à noção de livre-arbítrio, esboçando para tanto, algumas vertentes teóricas que propõem visões plurais para a liberdade humana como fundamento último da culpabilidade, inclusive com perspectivas que almejam uma superação do livre-arbítrio.

Buscar-se-á demonstrar que as teorias da culpabilidade não lograram êxito, exceto por artifícios nominalistas, em criar um modelo de Direito penal inequivocamente dissociado do livre-arbítrio, ainda que este seja visto como uma presunção, tal qual ocorre na ideia de responsabilidade (composta pela reprovabilidade somada a fins preventivos) de Claus ROXIN, ou ainda na tentativa de uma construção de uma culpabilidade procedimental (concebida por Klaus GÜNTHER), legitimada pela possibilidade de deliberação dos cidadãos na consecução das normas.

Assim, o livre-arbítrio faz-se presente nos modelos teóricos preponderantes a respeito da culpabilidade. Todavia, propõe-se um modelo que deixe de lado o debate acerca da legitimação do jus puniendi em razão dos indivíduos possuírem livre-arbítrio (que deve ser pressuposto) e considere um elemento que pode ser verificável na aplicação do Direito penal sobre alguém. Tal elemento é a autodeterminação, sendo certo que se ela é variável, em algumas situações, é possível inferir que um grau maior ou menor de autodeterminação tem direta relação com a realização de um comportamento delitivo.

Ao final do referido capítulo, algumas linhas introdutórias serão escritas a respeito da coculpabilidade, como uma proposta apta a aproximar a culpabilidade jurídico-penal da autodeterminação, a partir de condicionantes sociais que guardam relação com a (não) atuação estatal, conforme o recorte proposto para a presente pesquisa.

O capítulo "6 - Autodeterminação, o ator situado e a coculpabilidade”, empreender-seá a análise da autodeterminação (na perspectiva de limitações relacionadas a condicionantes sociais) como um elemento central à culpabilidade jurídico-penal, uma vez que a partir dele é possível estabelecer parâmetros mais consentâneos à ideia de proporcionalidade da pena, pois haverá um menor grau de reprovabilidade em certos crimes cometidos por um sujeito com uma autodeterminação reduzida em razão de omissões estatais na oferta de bens sociais. 
Para tanto, a autodeterminação será contextualizada por meio da noção de "ator situado", sendo que nas hipóteses em que o "ator" fizer parte de um cenário permeado de condicionantes sociais decorrentes de omissões estatais, será possível recorrer à coculpabilidade como instituto de mitigação do rigor da penalização, voltado à redução da seletividade penal e de uma racionalização na aplicação do Direito penal, adequando-o ao seu princípio da proporcionalidade, bem como a sua conformação mínima, contraposta à tendência contemporânea de recrudescimento da política criminal.

De modo a instrumentalizar a ideia de coculpabilidade, serão esboçadas as possibilidades de positivação no ordenamento pátrio, a partir de ponderações calcadas na realidade do Direito penal brasileiro, por exemplo nas esparsas menções jurisprudenciais à expressão, bem como em uma breve análise da positivação de tal ideia em outros países.

Por fim, há ponderações a respeito da coculpabilidade em face de elementos como seletividade e populismo penal, a partir de uma avaliação das possibilidades da coculpabilidade como instrumento de efetivação da valoração da autodeterminação dentro da dinâmica do Direito penal.

Adverte-se que, como opção metodológica, visando a manter uma uniformização do texto, empreendeu-se ao longo da tese o uso de traduções livres para o português de excertos no idioma espanhol, inglês e francês, salvo nas hipóteses de textos literários, os quais poderiam perder a métrica, rimas e sonoridade se traduzidos do idioma original. Em tais casos, optouse por transcrições à língua portuguesa em notas de rodapé. 


\section{1 - O LIVRE-ARBÍTRIO COMO PROBLEMA CENTRAL À EXISTÊNCIA HUMANA}

Two roads diverged in a yellow wood, And sorry I could not travel both

And be one traveler, long I stood

And looked down one as far as I could

To where it bent in the undergrowth; ${ }^{9}$

Robert Frost

A História da Filosofia aponta que há milênios pensadores escolheram a ideia de livrearbítrio ${ }^{10}$ como um tema crucial na definição dos atributos do ser humano, sendo que tal questão perdura na atualidade.

O parágrafo acima, com características típicas de um início de texto acadêmico, já apresenta em sua primeira linha uma aporia, pelo simples uso do verbo "escolheram" em sua construção. Tal expressão é exemplar no sentido de encerrar em si o cerne do debate acerca de nossa liberdade de decisão, tendo em vista que a própria "escolha" da questão que versa sobre termos, ou não, possibilidade de escolha já encerra em si uma possível contradição lógica, uma vez que, para um defensor da ausência de livre-arbítrio a noção de escolha não passa de obra ficcional ou de mal-entendido no emprego da linguagem.

A "opção" heterodoxa da forma de abertura deste capítulo, já denunciando em sua primeira linha um problema terminológico, parecerá, para alguns, inadequada e condenável, tendo em vista a melhor técnica de redação científica. Para outros, no entanto, terá méritos por fugir de clichês que permeiam a escrita acadêmica.

\footnotetext{
${ }^{9}$ FROST, Robert. The Road Not Taken. In: Mountain Interval. Nova Iorque: Henry Holt and Co., 1931, p. 9. Tradução livre para o português: "Duas estradas divergiam em um bosque de outono; ressenti-me não poder ambas tomar; E, sendo um único viajante, detive-me longamente; e contemplei um dos caminhos o quanto pude; até onde por sob a relva desaparecia."

${ }^{10}$ Termo que pode ser compreendido descrevendo a existência da possibilidade de se ter optado por uma decisão distinta da que de fato foi tomada. Cf. SEARLE, John. Freedom and Neurobiology. Reflexions on Free Will, Language and Political Power. Nova Iorque: Columbia University, 2007. Cabe apontar que o conceito exposto é uma espécie de denominador comum acerca do que se concebe como livre-arbítrio, sendo que SEARLE discorre ao longo de sua obra sobre algumas perspectivas que enfrentam a temática, orientando-se, por fim, ao chamado naturalismo biológico. Nessa esteira, cf. o subcapítulo "3.3 - Neurociência e liberdade de ação".
} 
No entanto, para além do louvor ou crítica acerca da abertura do texto, o que interessa evidenciar a partir de tal premissa é a seguinte problematização: caso inexista a liberdade de decisão (hipótese defendida por diversos pensadores contemporâneos e de outrora), a "opção" por determinada forma de iniciar um texto foi, em absoluto, falaciosa, eis que se desvelou a única e necessária sucessão de atos possíveis. Nesse sentido, a reação de desaprovação ou aprovação de cada leitor, por seu turno, nada mais seria do que a única reação possível diante do que fora a ele apresentado.

Levando às últimas consequências a premissa apresentada: a própria discussão que aqui se descortina a respeito do livre-arbítrio é uma ocorrência necessária, carente de qualquer discricionariedade ${ }^{11}$. Assim, para aqueles que defendem o determinismo ${ }^{12}$, não há espaço de liberdade nem no momento em que se discute se somos livres. A própria opção pela defesa da ausência de liberdade não consiste numa escolha entre duas possibilidades, mas sim em algo de antemão estabelecido e inexorável, que apenas não vislumbramos em virtude de não dominarmos todas as variáveis que influenciam a realidade. Se houvesse um ser com uma inteligência suficientemente potente para conhecer integralmente as relações causais, de acordo com o determinismo, tal ser seria apto a prever tudo o que viesse a acontecer. Pierre-Simon, Marquês de LAPLACE esboça uma entidade com tal capacidade, que ficou conhecida como o “demônio laplaceano":

Devemos considerar o estado atual do universo como o seu efeito antes e, como a causa do que se segue. Uma inteligência que por um instante dado sabia todas as forças com que a natureza é animada e a situação respectiva dos seres que a compõem, se de fato fosse grande o suficiente para enviar esses dados para análise, abraçar na mesma fórmula os movimentos dos maiores corpos do universo e aqueles do átomo mais leve: nada seria incerto para ela, e o futuro como o passado, estaria presente aos seus olhos. ${ }^{13}$

\footnotetext{
11 “As teorias científicas presumem que somos seres racionais livres para observar o Universo como quisermos e tirar conclusões lógicas daquilo que observamos. Num esquema como este, é razoável supor que seremos capazes de progredir cada vez mais em direção às leis que governam o Universo. Contudo, se houver realmente uma teoria unificada ela também determinará presumivelmente as nossas ações. E assim, a própria teoria determinaria o resultado da nossa busca. E por que motivo determinaria que chegássemos às conclusões certas, a partir da evidência? Não poderia também determinar que chegássemos à conclusão errada? Ou a nenhuma conclusão?" HAWKING, Stephen. Uma breve história do tempo. Tradução de Ribeiro da Fonseca. Lisboa: Círculo de leitores, 1988, p. 22.

${ }^{12} \mathrm{O}$ determinismo basicamente consiste "na tese de que em cada momento dado há exatamente um único futuro possível”. VAN INWAGEN, Peter. An essay on free will. Oxford: Clarendon Press, 1983, p. 3.

${ }^{13}$ LAPLACE. Essai philosophique sur les probabilités. In: Oeuvres, vol. II. Gauthier, Villars, 1986, pp. 6-7. Karl POPPER, em um argumento que serve de premissa a sua crítica ao determinismo, esboça sua própria versão de um ser onisciente (a qual acabou ficando conhecida, por referência à metáfora de LAPLACE, como demônio de
} 


\section{CONCLUSÕES}

1. O livre-arbítrio é fundamento do arcabouço sobre o qual está estruturada a humanidade. Uma realidade sem livre-arbítrio só poderia ser concebida com drásticas mudanças em toda cultura humana, uma vez que noções como culpa e mérito (bem como suas consequências sancionatórias e premiais) perderiam totalmente seus significados.

2. Conquanto toda cultura humana seja orientada a partir do livre-arbítrio como pressuposto, há posições teóricas que refutam sua real existência e defendem que tudo aquilo que compõe a realidade é regido pela necessidade. Tal posição corresponde à corrente denominada de determinismo radical. Há ainda posições que aceitam a existência do livrealvedrio humano, seja a partir de correntes indeterministas ou, ainda, por meio de posições compatibilistas, as quais possuem nuances, mas, como regra geral, defendem a coexistência entre o livre-arbítrio e as leis deterministas que regem o universo.

4. Uma das grandes questões filosóficas é: "Há livre-arbítrio?” Há milênios pensadores buscam responder tal indagação. De tais esforços, surgiram diversas teorias metafísicas em defesa ou refutação da liberdade humana, sendo certo que o próprio conceito de liberdade é problemático, eis que o vocábulo é polissêmico e não permite uma interpretação unívoca, sem que haja uma contextualização. Assim, a tarefa filosófica por excelência (criar conceitos) voltou-se e volta-se não só à busca pela resposta acerca da existência do livre-arbítrio, mas também e, a prioris à definição de um conceito para tal categoria.

5. A questão a respeito da existência ou não do livre-arbítrio também foi investigada pela Ciência, a partir de diversas miradas, sendo que, não raro, penalistas buscaram aportes científicos para sustentar suas posições dogmáticas acerca da liberdade de agir do ser humano, não obstante inexista uma resposta peremptória, qualquer que seja o ramo científico a ser utilizado como alicerce para uma tomada de posição.

6. a ideia de liberdade de vontade é construída socialmente e calcada na experiência, a partir de uma sensação de sentir-se livre para deliberar. Sob a ótica da Filosofia da linguagem, a noção de liberdade fundamenta as práticas dos indivíduos em sociedade, fazendo-se presente nos jogos de linguagem que permeiam as relações humanas. Assim, não faz sentido, dentro dessa perspectiva filosófica, indagar a respeito da existência ou não do livre-arbítrio, eis que tal resposta pertence a ordem do inefável, sendo que a solução para essa (não) questão se dá pela 
percepção da liberdade de ação presente na prática linguística e social, nas palavras e ações cotidianas.

7. Dessa forma, a solução para o impasse (apenas um mal-entendido linguístico, de acordo com a Filosofia da linguagem) a respeito da existência do livre-arbítrio se dá por uma análise dos jogos de linguagem compartilhados e operados pelos indivíduos, jogos os quais pressupõem a liberdade de ação humana. Portanto, o livre-arbítrio deve ser presumido. Qualquer passo além ou aquém disso corresponde a mera ilação, eis que pertence à ordem do inefável a resposta para a existência ou não do livre-alvedrio do ser humano.

8. Considerando-se a incognoscibilidade da solução do dilema do livre-arbítrio (a despeito de pensadores há milênios buscarem uma resposta para tal questão), o renitente debate sobre o livre-arbítrio dentro do Direito penal parece infrutífero. A dogmática jurídico-penal não pode ser construída sobre uma resposta peremptória sobre o livre-arbítrio (eis que tal resposta é inexistente), restando, dessa forma, que o Direito penal também trabalhe a liberdade de ação humana (um fundamento indissociável à culpabilidade) a partir da chave do livre-alvedrio como presunção.

9. É disfuncional qualquer uso do livre-arbítrio pelo Direito penal que vá além dessa presunção comungada coletivamente. Assertivas como "o indivíduo agiu sem livre-arbítrio" são inverificáveis e, mais ainda, sob o crivo de uma "Filosofia terapêutica" (ou seja, de esclarecimento lógico-gramatical), tal afirmação é sem sentido, eis que o livre-arbítrio não é um conceito de matizes, mas sim, uma categoria absoluta. Surge, a partir desse panorama, a imperiosidade da dogmática jurídico-penal operar com um conceito instrumentalizável, apto a trazer em seu bojo nuances que correspondam aos graus de liberdade que os indivíduos possuam concretamente.

10. Assim, o livre-arbítrio é um conceito absoluto, que consiste numa presunção de liberdade de agir do ser humano (tendo por pressuposto a existência de possibilidades de condutas diante de uma mesma situação). Isso significa dizer que a ideia de livre-alvedrio carece de uma solução para um questionamento acerca de quanta liberdade de agir dispõe um ser humano diante de um quadro fático qualquer.

11. A autodeterminação, por seu turno, consiste na capacidade do sujeito poder se comportar com diversos graus de autonomia, os quais dependem do número e intensidade das condicionantes que afetam sua capacidade de deliberação e externalização ou não de uma 
conduta no plano concreto. Dessa forma, a autodeterminação, diferentemente do livre-arbítrio, não é absoluta e pode ser concretamente restringida por circunstâncias que atuam na formulação de escolhas individuais e nas possibilidades de realização de tais escolhas.

12. Uma vez que a autodeterminação não é um conceito absoluto, possuindo matizes que dependem de variáveis que condicionam as decisões e o comportamento dos indivíduos, parece fundamental considerar essas diferenciações no momento de atribuição da responsabilidade de um sujeito por uma conduta. Tal premissa vale para a imputação de uma conduta delituosa a alguém. Ou seja, há que se considerar a ideia de autodeterminação na atribuição da culpabilidade (qualquer que seja sua vertente teórica ou sua denominação) jurídico-penal.

13. No entanto, há dificuldades na instrumentalização da autodeterminação pelo Direito penal no que concerne a algumas categorias de condicionantes (físicas e biológicas). São as condicionantes sociais que aparentam mais aptidão a uma instrumentalização pelo Direito penal, com vistas à construção de uma teoria da culpabilidade alinhada ao princípio da proporcionalidade e, concomitantemente, apta a ir de encontro à notável seletividade do sistema criminal.

14. No que concerne à culpabilidade, sob o prisma penal (é dizer, como reprovabilidade subjetiva), não parece ter havido nenhuma teoria de ressalto que logrou êxito em superar o alicerce do livre-arbítrio de forma peremptória, sem quaisquer resquícios da ideia e, concomitantemente, sem jogar por terra a possibilidade de um Direito penal calcada na culpa e não apenas na periculosidade do indivíduo.

15. Dada a já referida incognoscibilidade da verdade sobre o livre-arbítrio, algumas teorias colocaram este como uma presunção (tal qual defende-se nessa tese). Nesse sentido, a ideia de responsabilidade, concebida por Claus ROXIN, a qual alberga a ideia de reprovabilidade já presente nos modelos anteriores de culpabilidade (como o modelo finalista welzeniano), mas também pressupõe a demonstração de necessidade da pena para a consecução de finalidades preventivas.

16. A culpabilidade do modelo funcionalista teleológico roxiniano (denominada de responsabilidade) é a que ainda demonstra possuir maior robustez teórica, aproximando dentro do elemento culpabilidade, a dogmática da política criminal. Tal modelo é o que serve de subsídio à presente tese, propondo-se, a partir dele e sem qualquer aporia em tal aproximação, 
a adoção da coculpabilidade como um elemento contingente da responsabilidade, com uma função de diminuição do juízo de reprovabilidade (e não de excludente de culpabilidade) em razão de uma corresponsabilização do Estado (via omissão que condicionou a autodeterminação do sujeito) pelo comportamento reprovável.

17. Nesse sentido, a autodeterminação de um sujeito sofre reduções em virtude de circunstâncias sociais, as quais diminuem o plexo de possibilidades que o indivíduo possui. Assim, em virtude, por exemplo, de privações de bens sociais (como instrução formal), as possibilidades de modos de vida do sujeito tornam-se mais restritas e sua biografia tende a uma menor pluralidade de trajetórias.

18. São circunstâncias sociais como a do exemplo anterior que permitem a aferição do grau de autodeterminação de alguém que cometeu um delito. Isso porque, utilizando uma expressão do criminólogo belga Christian DEBUYST, o criminoso (bem como qualquer indivíduo, em qualquer posição social e contexto) é um "ator situado". Sendo assim, seu comportamento está condicionado às circunstâncias do cenário ao qual ele pertence no espaçotempo. Todavia, tal exame das condicionantes sociais jamais permite conclusões simplistas, é dizer, atribuindo uma causa unívoca à perpetração de um injusto penal.

19. Dentro da dinâmica das condicionantes sociais, tem-se limitações do plexo de possibilidades dos indivíduos em razão de omissões do Estado no que concerne a oferta de bens sociais, denominados na Constituição Federal brasileira de "direitos sociais" (previstos no artigo $6^{\circ}$ da Carta Magna). Há uma heterogeneidade social e nas oportunidades de acesso, por meios lícitos, a metas culturais homogêneas (patrimônio, acesso ao consumo, prestígio social), sendo certo que o Estado contribui para tal dinâmica, inclusive por meio da falta ou insuficiência de políticas públicas inclusivas.

20. A "coculpabilidade" parece ser um vetor privilegiado na tentativa de transmutar em linguagem normativa o conceito de autodeterminação, especificamente no caso de condicionantes sociais que decorrem da atuação deficitária do Estado na oferta de bens sociais. A coculpabilidade é um elemento a ser valorado no exame da culpabilidade do sujeito delitivo. Ao se analisar a reprovabilidade pelo injusto penal, há que levar em consideração, se cabível pelo tipo de delito e circunstâncias do "ator situado", uma eventual corresponsabilização do Estado. Em caso positivo, há um decréscimo na reprovabilidade do sujeito e, por conseguinte, uma mitigação da pena. 
21. Tal raciocínio pode ser descrito na seguinte afirmação: Se o Estado é deficitário na oferta de direitos sociais que acabam por reduzir o plexo de possibilidades de um sujeito, isso há que ser considerado na reprovabilidade desse indivíduo, tendo por norte os princípios da proporcionalidade e individualização da pena. Em síntese: o Estado só pode exercer de forma integral o jus puniendi se também exercer de forma integral sua incumbência de ofertar direitos sociais.

22. Optou-se, após um percurso que analisou criticamente demais hipóteses, por sugerir a adoção da coculpabilidade pelo ordenamento brasileiro como uma causa de diminuição de pena que seria positivada no Código penal nos seguintes termos: “Art. 22-A - A pena deve ser reduzida de um a dois terços, se reconhecida como contributiva à conduta delitiva a condição de vulnerabilidade do agente, caracterizada por sua situação econômica e social, ocasionadas pela privação ou precariedade na oferta de direitos sociais."

23. Portanto, a coculpabilidade, em virtude da situação de carência e estigmatização do criminalizado, não gera uma exclusão do crime em razão de inexigibilidade de conduta diversa ou qualquer instituto congênere. O modelo proposto nessa tese, pelos fundamentos expostos ao longo do texto, não é consentâneo à exclusão da culpabilidade como consequência de seu reconhecimento. A coculpabilidade, nos moldes aqui delineados, serve como minorante que, com base na supressão das possibilidades individuais do sujeito em virtude da omissão estatal na oferta de bens sociais, diminui a intensidade do apenamento em concreto.

24. Fugindo da interpretação canônica da teleologia do Direito penal como instrumento de proteção de bens jurídicos, alguns penalistas e criminólogos enxergam o Direito penal como uma ferramenta irracional que não justifica sua razão de ser quando aplicada à realidade. Para outros, o Direito penal como um instrumento racionalmente concebido para se legitimar a partir de afetos (irracionais) da coletividade, haja vista ser notável na sociedade uma espécie de fascínio pela punição, bem como uma ingênua crença na efetividade do Direito penal em sua finalidade manifesta de contenção da violência criminal.

25. Ambas as posições mencionadas acima parecem trazer acertos em seus diagnósticos acerca da realidade jurídico-penal. No entanto, seja o Direito penal ele próprio irracional ou seja o Direito penal utilizando da irracionalidade coletiva para legitimar-se e perpetuar-se, há que se indagar: qual é a solução factível para a superação desse instrumento eivado de externalidades? É possível abdicar do Direito penal? 
26. Conforme demonstrado, a definitiva abolição do Direito penal seria medida que também traria consigo uma série de externalidades, havendo que se pensar (racionalizar) em uma conformação do Direito penal que saia do atual estado de hiperinflação e rume para um patamar mínimo (o que é distinto de patamar nenhum, tal qual propõem autores alinhados ao abolicionismo penal).

27. Sob alguns olhares céticos, aparenta ser uma solução ingênua buscar racionalizar um instrumento supostamente irracional e feito para ser dessa forma. Todavia, propostas de racionalização do Direito penal trazem em seu bojo um discurso de resistência, pois visam ao alinhamento do sistema criminal com os valores democráticos e o conjunto principiológico que, ao menos em teoria, alicerça o Direito penal.

28. Para mais além, medidas racionalizadoras que sejam factíveis à aplicação prática têm o potencial de reverberar sobre casos concretos e, por conseguinte, alcançar sujeitos sobre os quais lançou-se o jus puniendi, cujo peso muitas vezes desproporcional transmuta réus em bodes expiatórios. Com supedâneo no pensamento kantiano, afirma-se o seguinte: se para ao menos um desses indivíduos (que são fins em si próprios), as propostas de racionalização servirem como elementos de contenção da desproporção (por exemplo, com o reconhecimento da coculpabilidade e a diminuição do quantum de aprisionamento), é o quanto basta.

29. Foge à pretensão dessa pesquisa esgotar o rendimento do conceito de autodeterminação como sucedâneo do problemático conceito de livre-arbítrio, no que concerne à verificação do patamar de liberdade de agir dos sujeitos (sendo tal verificação um parâmetro essencial ao juízo de reprovabilidade diante de um injusto penal). A despeito do livre-alvedrio, como conceito estanque, a autodeterminação aparenta ser uma categoria que melhor se adequa às nuances que correspondem aos graus de liberdade dos sujeitos em concreto, ou seja, dos "atores situados".

30. A proposta de positivação da coculpabilidade no ordenamento brasileiro é apenas um exemplo de como a mirada sobre a autodeterminação permite um aperfeiçoamento do Direito penal, contribuindo para o objetivo de contenção do jus puniendi, sobretudo no que concerne aqueles que correspondem à clientela de um Direito penal seletivo e voltado à gestão da miséria via criminalização, em vez da oferta de bens sociais previstos constitucionalmente. 


\section{REFERÊNCIAS}

ABBAGNANO, Nicola. Possibilità e libertà. Turim: Taylor, 1956.

ABRAMOVAY, Miriam. et al. Juventude, violência e vulnerabilidade social na América Latina: desafios para políticas públicas. Brasília: Unesco, 2002.

ADORNO, Sérgio. A gestão urbana do medo e da insegurança: violência, crime e justiça penal na sociedade brasileira contemporânea. Tese de Livre-docência em Sociologia, FFLCH/USP, São Paulo, 1996.

ADLER, Mortimer J. The Idea of Freedom. Nova Iorque: Greenwood, 1958.

AGOSTINHO DE HIPONA. O livre-arbítrio. Tradução de Nair Assis de Oliveira. São Paulo: Paulus, 1995.

AGRA, Cândido da. Elementos para uma epistemologia da criminologia. In: Estudos em Comemoração dos cinco anos (1995-2000) da Faculdade de Direito da Universidade do Porto. Coimbra: Coimbra Editora, 2001.

ALCÁCER GUIRAO, Rafael. Los fines del derecho penal: uma aproximación desde la filosofia política. Bogotá: Universidad Externado de Colombia, 2004.

ALEKSANDROWICZ, Ana Maria C.; MINAYO, Maria Cecília De Souza. Humanismo, liberdade e necessidade: compreensão dos hiatos cognitivos entre ciências da natureza e ética. In: Ciência \& Saude Coletiva, v. 10, n. 3, p. 513-26, 2005.

ALEXANDER, Larry. Criminal and Moral Responsability and the Libet experiments. In: NADEL, Lynn; SINNOTT-ARMSTRONG, Walter (orgs.). Concious will and responsability. Oxford: Oxford University Press, 2011.

ALQUIÉ, Ferdinand. Leçons sur Descartes. Science et métaphysique chez Descartes. Paris: La Table Ronde, 2005.

ALVAREZ, Marcos César. Bacharéis, Criminologistas e Juristas: saber jurídico e nova escola penal no Brasil (1889-1930). Tese de Doutorado em Sociologia. Faculdade de Filosofia, Letras e Ciências humanas da Universidade de São Paulo, São Paulo, 1996.

ALVES, José Antônio. Limites da Consciência. Porto: Fronteira do Caos Editores, 2013.

ANDRADE, Vera Regina Pereira de. Dogmática e controle penal: em busca da segurança jurídica prometida. In: ROCHA, Leonel Severo (Org.). In: Teoria do Direito e do Estado. Porto Alegre: Sérgio Antônio Fabris, 1994.

Sistema penal máximo $\mathbf{x}$ cidadanina mínima: códigos da violência na era da globalização. Porto Alegre: Livraria do Advogado, 2003. 
ANIYAR DE CASTRO, Lola. Criminologia da Reação Social. Tradução de Ester Kosovski. Rio de Janeiro: Forense, 1983.

La Criminologia crítica em el siglo XXI como criminologia de los derechos humanos y la contra-reforma humanística o las teorias criminológicas no son inocentes. In: Revista Brasileira de Ciências Criminais. São Paulo, jan./fev. 2009.

ARISTÓTELES. Ética a Nicómaco. Tradução de António de Castro Caeiro. Lisboa: Quetzal, 2004.

Metafísica. Tradução de Marcelo Perine. São Paulo: Loyola, 2001.

ARRIGO, Bruce A.; WILliAMS, Christopher R. (orgs.). Philosophy, Crime and Criminology. Chicago: University of Illinois Press, 2006.

AUBENQUE, Pierre. Le problème de l'être chez Aristote: essai sur la problématique aristotélicienne. Paris: Presses Universitaires de France, 1991.

BARATTA, Alessandro. Criminologia Crítica e crítica do Direito penal: introdução à sociologia do direito penal. $3^{\mathrm{a}} \mathrm{ed}$. Tradução de Juarez Cirino dos Santos. Rio de Janeiro: Revan, 2002.

BARBARAS, Renauld. O corpo da liberdade. In: NOVAES, Adauto (org.). O avesso da liberdade. São Paulo: Companhia das letras, 2002.

BARBOUR, Julian. The End of Time: The next revolution in our understanding of the universe. Londres: Weidenfeld \& Nicolson, 1999.

BAREL Yves. La marginalité sociale. Grenoble: PUG, 1979.

Le Paradoxe et le système. Essai sur le fantastique social. Grenoble: PUG, 1989.

BARROS, Bruna Gonçalves Loureiro de Andrade. Culpabilidade: análise crítica do conceito com base na ideia de vulnerabilidade. Dissertação de mestrado em Direito. Faculdade de Direito da Universidade de São Paulo, São Paulo, 2017.

BATISTA, Nilo. Introdução crítica do direito penal. Rio de Janeiro: Revan, 2011.

BAUMAN, Zygmunt. Vida para consumo: a transformação das pessoas em mercadorias. Tradução de Carlos Alberto Medeiros. Rio de Janeiro: Jorge Zahar, 2008.

BECCARIA, Cesare. Dos delitos e das penas. Tradução de Deocleciano Torrieri Guimarães. São Paulo: Martin Claret, 2006.

BECHARA, Ana Elisa Liberatore Silva. Bem jurídico-penal. São Paulo: Quartier Latin, 2014. 
. Valor, norma e injusto penal: Considerações sobre os elementos normativos do tipo objetivo no Direito Penal contemporâneo. Tese de titularidade em Direito penal. Faculdade de Direito da Universidade de São Paulo, São Paulo, 2017.

BECKER, Howard. Outsiders: studies in the sociology of deviance. Nova Iorque: The Free Press, 1966.

BENJAMIN, Walter. Destino e carácter. Tradução de João Barrento. Covilhã: LusoSofia, 2011.

BENNET, M. Hacker, P. La polémica. In: Bennet, M. et al. La naturaleza de la conciencia: cerebro mente y lenguaje. Barcelona: Paidós, 2008.

BERDUGO GÓMEZ DE LA TORRE, Ignacio et al. Curso de derecho penal. Parte general. Barcelona: Ediciones Experiencia, 2004.

BERGER, Gaston. Phénoménologie du temps et prospective. Paris: PUF, 1964.

BERGER, Peter. Perspectivas Sociológicas: uma visão humanística. Tradução de Donaldson M. Garschagen. Rio de Janeiro: Vozes, 1986.

BERGSON, Henri. Essai sur les données imediates de la conscience. Paris: PUF, 2007.

BERLIN, Isaiah. Four essays on liberty. Oxford: Oxford University Press, 1969.

BEYSSADE, Michelle. A doutrina da liberdade de Descartes: diferenças entre os textos francês e latino da Quarta meditação. In: Analytica, Rio de Janeiro, vol 13 n 2, p. 225-242, 2009.

BITENCOURT, Cezar Roberto. Tratado de direito penal. $8^{a}$ ed. São Paulo: Saraiva, 2003.

BLUMER, Herbert. Symbolic Interactionism: Perspective and Method. Nova Jérsei: PrenticeHall, 1969.

BOBBIO, Norberto. Igualdade e liberdade. Tradução de Carlos Nelson Coutinho. Rio de Janeiro, Ediouro, 2000.

. La función promocional del Derecho. Tradução de Miguel Afonso Ruiz. In MIGUEL, Alfonso Ruiz (org.). Contribuición a la teoria del Derecho. Madri: Editorial Debate, 1990.

BOHM, David. A totalidade e a ordem implicada. Tradução de Mauro de Campos e Silva. São Paulo: Cultrix, 2001.

BOHR, Niels. Atomic Theory and the Description of Nature. Cambridge: Cambridge University Press, 1961.

BONNEAU, Cristiano. Leibniz e Hegel: em torno da questão dos princípios de Razão Suficiente e Identidade. In: Aufklärung: revista de filosofia, v. 2, n. 1, p. 135-148, 2015. 
BORNHEIM, Gerd. As medidas da liberdade. In: NOVAES, Adauto (org.). O avesso da liberdade. São Paulo: Companhia das letras, 2002.

BRACHTENDORF, Johannes. Confissões de Agostinho. Tradução de Milton Camargo Mota. São Paulo: Edições Loyola, 2008.

BRANDÃO, Cláudio. Culpabilidade: sua análise na dogmática e no direito penal brasileiro. In: Revista da associação brasileira de professores de ciências penais, v. 1, ano 1, p. 171-184, jul./dez. 2004.

BRIDGMAN, Percy Williams. The Nature of Physical Theory. Nova Iorque: Dover, 1936.

BROCHU, Serge; BRUNELLE, Natacha; COUSINEAU, Marie-Marthe. Des cheminements vers un style de vie déviant: adolescents des centres jeunesse et des centres pour toxicomanes. In: Les cahiers de recherches criminologiques, n. 27. Montreal: Universidade de Montreal, 1998.

BURKHARDT, Björn et al. El problema de la libertad de acción en el derecho penal. Tradução de Rafael Alcácer Guirao e Bernardo Feijoo Sánchez. Buenos Aires: Ad-Hoc, 2007.

BUSATO, Paulo César. Apontamentos sobre o dilema da culpabilidade penal. In: Revista Justiça e Sistema Criminal. vol. 3, n. 5, pp. 237-278, jul./dez. 2011

. Direito penal e ação significativa: uma análise da função negativa do conceito de ação em direito penal a partir da filosofia da linguagem. Rio de Janeiro: Lumen Juris, 2010.

(org.). Neurociência e direito penal. São Paulo: Atlas, 2014.

BUSTOS RAMÍREZ, Juan. Lecciones de Derecho Penal. Madrid: Trotta, 2006.

Manual de Derecho Penal Español. Parte General. Barcelona: Ariel, 1984.

CAMARGO, Antonio Luis Chaves. Culpabilidade e reprovação penal. São Paulo: Saraiva, 1994.

CAMPBELL, Charles Arthur. Is Free will a Pseudo-Problem? In: Mind, v. 60, n. 240, p. 441465, 1951.

CAPITA, Pascoal Mangovo. A pessoa como Liberdade da Vontade em Harry Frankfurt. Dissertação de mestrado em Filosofia. Faculdade de Letras da Universidade do Porto, Porto, 2016.

CAPRA, Fritjof. O ponto de mutação. Tradução de Álvaro Cabral. São Paulo: Cultrix, 2002.

CARBONEL MATEU, Juan Carlos, Derecho penal: Conceptos y principios constitucionales. Valência: Tirant lo blanch, 1996. 
CARRARA, Francesco. Programa de derecho criminal. Tradução de José Ortega Torres. Bogotá: Temis, 1956.

CARVALHO, Amilton Bueno de; CARVALHO, Salo de. Aplicação da pena e garantismo. Rio de Janeiro: Lumen Juris, 2002.

CARVALHO, Salo de. A co-responsabilidade do Estado nos crimes econômicos: fundamentos doutrinários e aplicabilidade judicial. Porto Alegre: Livraria do Advogado, 2008.

Antimanual de criminologia. $2^{\text {a }}$ ed. Rio de Janeiro: Lumen Juris, 2008.

. Memória e esquecimento nas práticas punitivas. In: Estudos Ibero-Americanos, $\mathrm{n}$. 2, p. 61-85, 2006.

CASTAIGNÈDE, Jocelyne. Hommage à Jean Pinatel et à son oeuvre. In: Eguzkilore, n. 13, pp. 219-225, 1999. Cf. ainda PINATEL, Jean. La criminologie. Paris: Spes, 1960.

CASTORIADIS, Cornelius. World in Fragments: Writings on Politics, Society, Psychoanalysis, and the Imagination. Stanford: Stanford University Press, 1997.

CASTRO, Douglas Camarano de. A aplicação da circunstância atenuante inominada em razão da teoria da co-culpabilidade. In: Boletim IBCCRIM, vol.: 13, nº 151, 2005.

CAVALCANTI, Eduardo Medeiros. Crime e sociedade complexa. Campinas: LZN, 2005.

CEREZO MIR, José. Culpabilidad y pena. In: Problemas Fundamentales del Derecho penal. Madrid: Tecnos, 1982.

El concepto material de culpabilidad. In: Revista Peruana de ciencias penales, ano III, $\mathrm{n}^{\circ}$ 6. Lima, 1995.

CHAUÍ, Marilena. A nervura do real: Imanência e Liberdade em Espinosa. São Paulo: Companhia das Letras, 1999.

CHOMSKY, Noam. Liberty and Language. Oxford: Oxford University Press, 1979.

CHOUDHURY, Suparna; BLAKEMORE, Sarah-Jayne. Intentions, Actions, and the Self. POCKETT, Susan (org.). In: Does Conciousness Cause Behavior? Cambridge: MIT press, 2000.

CHRISTIE, Nils. Uma razoável quantidade de crime. Tradução de André Nascimento. Rio de Janeiro: Revan, 2011.

COQUARTD, Oliver. Marat. Tradução de C. H. Silva. São Paulo: Scritta, 1996.

COOPER, David Edward. Filosofias do mundo: uma introdução histórica. Tradução de Dinah de Abreu Azevedo. Edicoes Loyola, 2002. 
CORNELLI, Roberto. Miedo, criminalidad y orden. Tradução de Flavia Valgiusti. Buenos Aires: BdeF, 2012.

COSTA, Edson Ferreira da. A noção de circunstância no raciovitalismo de Ortega Y Gasset. Dissertação de Mestrado em Filosofia. Universidade Federal do Ceará, Fortaleza, 2010.

COSTA, José de Faria. Uma ponte entre o direito penal e a filosofia penal: lugar de encontro sobre o sentido da pena. In: MIRANDA, Jorge; SILVA, Marco Antonio Marques da (orgs.). Tratado luso-brasileiro da dignidade humana. São Paulo: Quartien Latin, 2008.

CRUZ, Valéria Álvares. O direito e a nova visão da ciência. São Paulo: Fiuza, 2000.

DAMÁSIO, ANTÓNIO. O erro de Descartes: emoção, razão e cérebro humano. São Paulo: Companhia das Letras, 2006.

DAVIDSON, Donald. Mental events. In: Beakley, B. e Ludlow, P. (eds.). The philosophy of mind: classical problems/contemporary issues. Cambridge: MIT Press, 1992.

DEBUYST, Christian. Les paradigmes du droit pénal et les criminologies cliniques. In: Criminologie, n. 25, vol. 2, pp. 49-72, 1992.

Pour introduire une histoire de la criminologie: les problématiques de départ. In: Déviance et société. Vol. 14, n 4. pp. 347-376, 1990.

. Présentation et justification du thème. In: DIGNEFFE, Françoise (org.). Acteur social et délinquance. Hommage à Christian Debuyst. Liège: Mardaga, 1990.

Qui récupère qui? In: Déviance et société. Vol 19, N. 3. pp. 257-265, 1995.

DELGADO GARCIA, José M. Hacia uma neurofisiologia de la libertad. In: DEMETRIO CRESPO, Eduardo (org.). Neurociencias y derecho penal: Nuevas perspectivas en el ámbito de la culpabilidad y tratamiento jurídico-penal de la peligrosidad. Madri: Edisofer, 2013.

DELEUZE, Gilles; GUATTARI, Félix. O que é a filosofia? Tradução Bento Prado Jr. e Alberto Alonso Muñoz. São Paulo: Editora 34, 1992.

DEMETRIO CRESPO, Eduardo. Compatibilismo humanista: Una propuesta de conciliación entre Neurociencias y Derecho Penal. In: DEMETRIO CRESPO, Eduardo (org.). Neurociencias y derecho penal: Nuevas perspectivas en el ámbito de la culpabilidad y tratamiento jurídico-penal de la peligrosidad. Madri: Edisofer, 2013.

Identidad y responsabilidad penal. In: Anuario de la Facultad de Derecho de la Universidad Autónoma de Madrid (AFDUAM), pp. 237-254, 2013.

DENNETT, Daniel C. Freedom Evolves. Londres: Penguin UK, 2004. 
DESCARTES, René. A carta a Mesland de 9 de fevereiro de 1645: tradução e comentários. Tradução de Geisa Mara Batista e Daniel Carrara. In: Kriterion. v. 49, n. 117, p. 235-242, 2008.

As paixões da Alma. Tradução de J. Guinsburg e Bento Prado Júnior. São Paulo: Abril cultural, 1979. (Coleção Os Pensadores).

. Meditações metafísicas. Tradução de J. Guinsburg e Bento Prado Júnior São Paulo: Abril cultural, 1979. (Coleção Os Pensadores).

DEUTSCH, David. The Fabric of Reality: The Science of Parallel Universes and Its Implications. Londres: Allen Lane, 1997.

DIAS, Jorge de Figueiredo. Direito Penal - Parte Geral, Tomo I, Coimbra: Coimbra Editora 2004.

DIAS, Jorge Figueiredo; ANDRADE, Manuel da Costa. Criminologia: o homem delinquente e a sociedade criminógena. Coimbra: Imprenta, 2013.

DIGNEFFE, Françoise (org.). Acteur social et délinquance: une grille de lecture du système de justice pénale. Libre en hommage au professeur Christian Debuyst. Liège: Mardaga, 1990.

DI MATTEO, Vincenzo. Ananké em o mal-estar na civilização: desamparo e compromisso ético. In: Revista Perspectiva Filosófica, vol VI, nº 11, jan-jun. de 1999.

DUARTE, David; PINHEIRO, Alexandre Sousa et al. Legística: perspectivas sobre a concepção e redacção de actos normativos. Coimbra: Almedina, 2002.

DURANTE, Felipe. Da estrutura à função: O direito penal em Arthur Schopenhauer. In: Revista Voluntas. Rio de Janeio, vol. 6, nº 2, 2015.

DURKHEIM, Emile. The rules of sociological method: and selected texts on sociology and its method. Tradução de H. D. Halls. Nova Iorque: Simon and Schuster, 2014.

EBERT, John David. O Fim da Divindade Mecânica. Tradução de Edvaldo Batista de Souza Brasília: Teosófica, 2012.

EDELMAN, Murray. The symbolic uses of politics. Marshall: University of Illinois, 1977.

EIDE, Erling. Economics of crime: deterrence and the rational ofender. Oslo: North-Holland, 1994.

ELIAS, Norbert. A Sociedade dos Indivíduos. Tradução de Vera Ribeiro. Rio de Janeiro: Jorge Zahar, 1996.

ENGISCH, Karl. La teoría de la libertad de la voluntad em la actual doctrina filosófica del derecho penal. Tradução de José Luis Guzmán Dalbora. Buenos Aires: Julio César Faira, 2008. 
. Liberdade, culpa, Direito Penal. $2^{\text {a }}$ ed. Coimbra: Biblioteca Jurídica Coimbra, 1983.

ÉSQUILO. Prometeu acorrentado. Tradução de Daisi Malhadas e Maria Helena de Moura Neves. Araraquara: UNESP, 1977.

FABRICIUS, Dirk. Culpabilidade e seus fundamentos empíricos. Tradução de Juarez Tavares. In: Afreudite-Revista Lusófona de Psicanálise Pura e Aplicada, v. 3, n. 5/6, 2007.

FÁH, Luzia et al. Un nuevo determinismo? La exclusión de las relaciones probabilísticas y de las influencias situacionales en los enfoques neurocientífico. In: BUENO ARÚS, Francisco et al (orgs.), Derecho penal y criminología como fundamento de la política criminal: estudios en homenaje al profesor Alfonso Serrano Gómez. Madri: Dykinson, 2006.

FEIJOO SÁNCHEZ, Bernardo. Derecho Penal y Neurociencias. Una relación tormentosa? Disponível em <http://www.indret.com/pdf/806.pdf> Acesso em 02/10/2015.

FEINBERG, Joel. Harm to self. Nova Iorque: Oxford, 1986.

FERRAJOLI, Luigi. Direito e razão. $3^{a}$ ed. Tradução de Ana Paula Zomer Sica et al. São Paulo: Revista dos Tribunais, 2002.

FERRI, Enrico. Princípio de direito criminal: o criminoso e o crime. Tradução de Luiz Lemos D’Oliveira. Campinas: Bookseller, 2003.

2006.

Sociología Criminal. Tradução de Soneli M. Melloni Farina. Sorocaba: Minelli,

FINDLAY, Mark. Problems for the Criminal Law. Melbourne: Oxford University Press, 2001.

FOUCAULT, Michel. A verdade e as formas jurídicas. $3^{\text {a }}$ ed. Tradução de Roberto Cabral de Melo Machado. Rio de Janeiro: Nau, 2002.

. As palavras e as coisas: uma arqueologia das ciências humanas. Tradução de Salma Tannus Muchail. São Paulo: Martins Fontes, 1999.

Surveiller et punir: naissance de la prison. Paris: Gallimard, 1999.

FRANK, Reinhard. Sobre la estructura del concepto de culpabilidad. Tradução de Gustavo Eduardo Aboso e Tea Löw. Buenos Aires: B de F, 2004.

FRANKFURT, Harry. Alternate Possibilities and Moral Responsability. In: WATSON, Gary (org.). Free Will. Nova Iorque: Oxford University Press, 2003.

Freedom of the Will and the Concept of a Person. In: The journal of philosophy, v. 68 , n. 1, p. 5-20, 1971. 
FREUD, Sigmund. O mal-estar na civilização. Tradução de José Otávio de Aguiar Abreu. Rio de Janeiro: Imago, 1974.

. Una dificuldad del psicoanálisis. In: Obras completas. Tradução de J. L. Etcheverry. Buenos Aires: Amorrortu, 1990.

FREUDENTHAL, Berthold. Culpabilidad y reproche en el derecho penal. Tradução de oséLuiz Guzmán Dalbora. Buenos Aires: B de F, 2006.

FUZIGER, Rodrigo. Direito penal simbólico. Curitiba: Juruá, 2015.

FEHR, E.; GACHTER, S. Altruistic punishment in humans. In: Nature, n. 415, 137-140, 2002.

GARFINKEL, Harold. Conditions of Successful Degradation Cerimonies. In: The American Journal of Sociology, vol. LXI, Chicago, 1956.

GARLAND, David. A cultura do controle. Crime e ordem na sociedade contemporânea. Tradução de André Nascimento. Rio de Janeiro: Revan, 2008.

GASPAR, Marcela Goulart; BAYER, Diego. Coculpabilidade e a responsabilização do Estado. In: Temiminós Revista Científica, v. 4, n. 2, p. 109-122, 2014.

GRANDI, Ciro. Multiculturalismo, imputabilidad y culpabilidad. In: DEMETRIO CRESPO, Eduardo (org.). Neurociencias y derecho penal: Nuevas perspectivas en el ámbito de la culpabilidad y tratamiento jurídico-penal de la peligrosidad. Madri: Edisofer, 2013.

GIMBERNAT ORDEIG, Enrique. Tiene um futuro la dogmática juridicopenal? In: Estudios de derecho penal. Madri: Tecnos, 1990.

GIRARD, René. A Violência e o Sagrado. Tradução de Martha Conceição Gambini. Rio de Janeiro/São Paulo: Paz e Terra/Editora da Unesp, 1990.

GOFFMAN, Erving. A representação do eu na vida cotidiana. Tradução de Maria Célia Santos Raposo. Petrópolis: Vozes, 1985.

GOLDMAN, Flavio. Direito quântico: revisitação e hipóteses de aplicação ao direito contemporâneo. Dissertação de mestrado em Direito. Pontifícia Universidade Católica de São Paulo, São Paulo, 2010.

GONDIM, Reno Feitosa. Epistemologia quântica \& direito penal - fundamentos para uma teoria da imputação objetiva do direito penal. Curitiba: Juruá, 2005.

GONSETH, Ferdinand. Déterminisme et libre arbitre. Paris: Dunod, 1944.

GOSWAMI, Amit et al. O universo autoconsciente. Rio de Janeiro: Rosa dos Tempos, 2003. 
GRANDI, Ciro. Multiculturalismo, imputabilidad y culpabilidad. In: DEMETRIO CRESPO, Eduardo (org.). Neurociencias y derecho penal: Nuevas perspectivas en el ámbito de la culpabilidad y tratamiento jurídico-penal de la peligrosidad. Madri: Edisofer, 2013.

GREENE, Joshua; COHEN, Jonathan. For the law, neuroscience changes nothing and everything. In: Philosophical Transactions of the Royal Society B, v. 359, n. 1451, 2004.

GUEROULT, Martial. Descartes selon l'ordre des Raisons. Paris: Aubier, 1968.

Leibniz. Dynamique et métaphysique suivi de note sur le principe de la moindre action chez Maupe. Paris: AubierMontaigne, 1967.

GUERRA, Renato de Souza. Dimensões do consumo na vida social. Tese de doutorado em Sociologia. Faculdade de Ciências Humanas da Universidade Federal de Minas Gerais, Belo Horizonte, 2010.

GUIMARÃES, Cláudio Alberto Gabriel. A culpabilidade compartilhada como princípio mitigador da ausência de efetivação dos direitos humanos fundamentais. In: Revista de informação legislativa, v. 46, n. 184, p. 55-66, 2009.

Funções da pena privativa de liberdade no sistema penal capitalista. Rio de Janeiro: Revan, 2007.

GÜNTHER, Klaus, Acción voluntaria y responsabilidad criminal. Tradução de Rafael Alcácer Guirao, In: GÜNTHER, Klaus; JAKOBS, Günther; BURKHARDT, Björn. El problema de la libertad de acción en el Derecho penal. Buenos Aires: Ad-Hoc, 2007.

A culpabilidade no Direito penal atual e no futuro. Tradução de Juarez Tavares. In: Revista Brasileira de Ciências Criminais (RBCCRIM), n. 24, outubro-dezembro, pp. 78-92, 1998.

HABERMAS, Jürgen. Direito e Democracia. Entre faticidade e validade. Vol. I. Tradução de Flávio Beno Siebeneichler. Rio de Janiero: Tempo Brasileiro, 2003.

Teoría de la acción comunicativa. Racionalidad de la acción y racionalidad social. Tradução de Manuel Jiménez Rendón. Madri: Taurus, 1987.

HAMPSHIRE, Stuart. Freedom of Mind and Other Essays. Princeton: Princeton University Press, 1971.

HARDIE, William Francis Ross. Aristotle and the freewill problem. In: Philosophy. Cambridge, v. 43, n. 165, p. 274-278, 1968.

HARE, R. M. Freedom and Reason. Oxford: Clarendon Press, 1985.

HART, Herbert. Punishment and Responsability. Londres: Oxford, 1968. 
HASSEMER, Winfried. ¿Alternativas al principio de culpabilidad?, Tradução de Francisco Muñoz Conde. In: Cuadernos de políticas criminales, Madri, nº 18, 1982.

- Características e crises do moderno Direito penal. In: Revista Síntese de Direito penal e processual penal, Porto Alegre, ano III, $\mathrm{n}^{\circ}$. 18, fev./mar., 2003.

. ¿Es la Autodeterminación todavía Actual? Tradução de Francisco Muñoz Conde. In: Revista Internacional de Pensamiento Político, Huelva, Vol. 3, pp. 239-257, 2015.

Fundamentos del derecho penal. Tradução de Francisco Muñoz Conde e Luiz ARROYO ZAPATERO. Barcelona: Bosch, 1984.

Introdução aos fundamentos do direito penal. Tradução de Pablo Rodrigo Alflen da Silva. Porto Alegre: Sergio Antonio Fabris, 2005.

Neurociencias y culpabilidad en derecho penal. Disponível em <http://www.indret.com/ pdf/821.pdf> Acesso em 03/10/2015.

Persona, mundo y responsabilidad: bases para una teoría de la imputación em derecho penal. Tradução de Francisco Muñoz Conde e María del Mar Díaz Pita. Santa Fe de Bogotá: Temis, 1999.

HAWKING, Stephen. Uma breve história do tempo. Tradução de Ribeiro da Fonseca. Lisboa: Círculo de leitores, 1988.

HAWKING, Stephen; MLODINOW, Leonard. The Grand Design. Nova Iorque: Bantam Books, 2010.

HEGEL, Georg Wilhelm Friedrich. A razão na História. Uma introdução geral à Filosofia da História. Tradução de Beatriz Sidou, São Paulo: Centauro, 2001.

Fontes, 1997.

Princípios da filosofia do direito. Tradução de Orlando Vitorino. São Paulo: Martins

HIRSCH, Hans Joachim. Acerca de la actual discusión alemana sobre libertad de voluntad y derecho penal. In: DEMETRIO CRESPO, Eduardo (org.). Neurociencias y derecho penal: Nuevas perspectivas en el ámbito de la culpabilidad y tratamiento jurídico-penal de la peligrosidad. Madri: Edisofer, 2013.

El desarrollo de la dogmática penal después de Welzel. Tradução de Mariano Bacigalupo. In: Revista brasileira de ciências criminais (RBCCRIM), n. 43, p. 11-30, 2003.

HONDERICH, Ted. A Theory of Determinism: The mind, neuroscience, and life-hopes. Oxford: Clarendon Press, 1988.

HORMAZÁBAL MALARÉE, Hernán. Una necesaria revisión del concepto de culpabilidad. In: Revista de derecho (Valdivia), v. 18, n. 2, p. 167-185, 2005. 
HOYER, Andreas. Accesibilidad normativa como elemento de la culpabilidad. In: DEMETRIO CRESPO, Eduardo (org.). Neurociencias y derecho penal: Nuevas perspectivas en el ámbito de la culpabilidad y tratamiento jurídico-penal de la peligrosidad. Madri: Edisofer, 2013.

HUlSMAN, Louk; CELIS, Jaqueline Bernart de. Penas Perdidas. O Sistema Penal em Questão. Tradução de Maria Lúcia Karam. Niterói, RJ: Luam, 1997.

HUME, David. A treatise of human nature. Oxford: Oxford University Press, 2006.

An enquiry concerning human understanding: a critical edition. Oxford: Clarendon Press, 2009.

HUSSERL, Edmund. A ideia da fenomenologia. Tradução de Artur Mourão. Lisboa: Edições 70, 2000.

Idéias para uma fenomenologia pura e para uma filosofia fenomenológica. Introdução geral à fenomenologia pura. Tradução de Marcio Suzuki. São Paulo: Ed. Idéias \& Letras, 2006.

JÄGER, Chistian. Libre determinación de la voluntad, causalidad y determinación a la luz de la moderna investigación del cerebro. In: DEMETRIO CRESPO, Eduardo (org.). Neurociencias y derecho penal: Nuevas perspectivas en el ámbito de la culpabilidad y tratamiento jurídico-penal de la peligrosidad. Madri: Edisofer, 2013.

JAPIASSÚ, Hilton; MARCONDES, Danilo. Dicionário Básico de Filosofia. $3^{\text {a }}$. ed. Rio de Janeiro: Jorge Zahar, 1991.

JAKOBS, Günther. El princípio de culpabilidad. In: Anuário de Derecho Penal y Ciências Penales, Madri, tomo XLV, fascículo I, janeiro-abril, 1992, pp. 1051-1083.

Individuo y persona. Sobre la imputación jurídico-penal y los resultados de la moderna investigación neurológica. Tradução de Bernardo Feijoo Sánchez. In: El problema de la libertad de acción en el Derecho penal. Buenos Aires: Ad-Hoc, 2007.

JHERING, Rudolph von. El elemento de la culpabilidad en el derechoprivado romano. Tradução de José Luis Guzmán Dalbora. Buenos Aires: B de F, 2013.

KAPLAN, Leonard V. Truth and/or Consequences: Neuroscience and Criminal Responsabiliy. In: POCKETT, Susan (org.). Does Conciousness Cause Behavior? Cambridge: MIT press, 2000.

KANE, Robert. Responsability, Luck, and Chance: Reflections on Free Will and Indeterminism. In: Journal of Philosophy, Ekstrom, 2001.

KANE, Robert. The significance of Free Will. Oxford: Oxford University Press, 1996.

KARAM, Maria Lúcia. A Esquerda Punitiva. In: Discursos Sediciosos: Crime, Direito, Sociedade. $\mathrm{n}^{\circ}$ 1, ano 1, Rio de Janeiro: Relume Dumará, 1996. 
KANT, Immanuel. Crítica da razão pura. Tradução Valério Rodhen. São Paulo, Editora Nova Cultura, 1999.

Fundamentação da metafísica dos costumes. Tradução de Guido Antônio de Almeida, São Paulo: Barcarolla, 2009.

KENNY, Anthony. La metafísica de la mente: filosofía, psicología, linguística. Tradução de Francisco Rodriguez Consuegra. Barcelona: Paidós, 2000.

KHALED JR, Salah Hassan. O problema da indemonstrabilidade do livre-arbítrio: a culpabilidade jurídico-penal diante da nova concepção de homem da neurociência. In: Sociologia Jurídica, n. 10, 2010.

KOONTZ, Dean. Innocence. Nova Iorque: Bantam, 2013.

KUHN, Thomas S. A Estrutura das Revoluções Científicas. Tradução de Beatriz Vianna Boeira. São Paulo: Perspectiva, 1997.

LAHIRE, Bernard. Retratos sociológicos: Disposições e variações individuais. Tradução de Didier Martin e Patrícia C. R. Reuillard. Porto Alegre: Artmed, 2004.

LARENZ, Karl. Metodologia da ciência do direito. Tradução de José Lamego. Lisboa: Fundação Calouste Gulbenkian, 1997.

LEIBNIZ, Gottfried Wilhelm. A monadologia. Tradução de Marilena Chauí. São Paulo: Abril, 1979. (Coleção os Pensadores).

Discurso de metafísica. Tradução de Marilena Chauí. São Paulo: Abril, 1979. (Coleção os Pensadores).

Ensaios de Teodiceia: sobre a bondade de Deus, a liberdade do homem e a origem do mal. Tradução de Juliana Cecci Silva. São Paulo: Liberdade, 2013.

Sistema novo da natureza e da comunicação das substâncias e outros textos. Tradução de Edgar Marques. Belo Horizonte: Editora UFMG, 2002.

LEMERT, Edwin. Social Pathology. Nova Iorque: Mcgraw-Hill, 1951.

LEMOS, Clécio José Morandi de Assis. Culpabilidade por vulnerabilidade. In: Boletim IBCCRIM, ano 17, nº 210, São Paulo, maio de 2010.

LEONI, Bruno. Liberdade e a lei. Tradução de Diana Nogueira e Rosélis Maria Pereira. Porto Alegre: Ortiz, 1993.

LEOPOLDO E SILVA, Franklin. Descartes: a metafísica da modernidade. São Paulo, Moderna, 1993. 
LESHAN, Laurence; MARGENAU, Henry. Einstein's Space and Van Gogh's Sky. Londres: Macmillan, 1982.

LESSA, Pedro. O determinismo psychico e a imputabilidade e responsabilidade criminaes. São Paulo: Typographia Duprat, 1905.

LEWIS, David. Are We Free to Break the Laws? In: WATSON, Gary (org.). Free Will. Nova Iorque: Oxford University Press, 2003.

Parts of Classes. Oxford: Blackwell Publishers, 1991.

LEYRET, Henry. Les jugements du président Magnaud: réunis et commentés. Paris: P. V. Stock, 1900.

LIBET, Benjamin. Do we have free will? Journal of consciousness studies, v. 6, n. 8-9, p. 4757, 1999.

The Volitional Brain: Towards a Neuroscience of Free Will. Exeter: Imprint, 2004.

Unconscious cerebral initiative and the role of conscious will in voluntary action. Behavioral and brain sciences, v. 8, n. 4, p. 529-539, 1985.

LICHTENBERG, Georg Christoph. Aphorismes. Tradução de Marthe Robert. Paris: J. J. Pauvert, 1966.

LISZT, Franz von. Tratado de direito penal allemão. Tradução de José Hygino Duarte Pereira. Brasília: Senado Federal, 2006.

LLOMPART VERD, José. Revisando las siete maravillas del Derecho penal, In: GUZMÁN DALBORA, José Luis (coord.). El penalista liberal. Buenos Aires: Hammurabi, 2004.

LOCKE, John, An Essay Concerning Human Understanding. Oxford: Oxford University Press, 1975.

LOUÇÃ, Francisco. Determinismo e Livre Arbítrio nas Ciências Sociais: Contributos Matemáticos. In: Revista de Economia Política, São Paulo, v. 21, n. 2, p. 154-176, 2001.

LUHMANN, Niklas. Sociologia do Direito, v. I. tradução de Gustavo Bayer. Rio de Janeiro: Tempo Brasileiro, 1983.

LUKÁCS, Georg. As Bases Ontológicas do Pensamento e da Atividade do Homem. n. 4. Tradução de Carlos Nelson Coutinho. São Paulo: Ciências Humanas, 1978.

LUZÓN PENA, Diego Manuel. Libertad, culpabilidad y neurociencias. In: DEMETRIO CRESPO, Eduardo (org.). Neurociencias y derecho penal: Nuevas perspectivas en el ámbito de la culpabilidad y tratamiento jurídico-penal de la peligrosidad. Madri: Edisofer, 2013. 
MAASEN, Sabine. Neurosociety Ahead? Debating Free Will in the Media. In: POCKETT, Susan (org.). Does Conciousness Cause Behavior? Cambridge: MIT press, 2000.

MACHADO, Marta Rodriguez de Assis. Punição, culpa e comunicação: é possível superar a necessidade da inflição de sofrimento no debate teórico sobre a pena? In: Revista da Faculdade de Direito - UFMG, Belo Horizonte, n. 69, pp. 389-414, jul./dez. 2016.

MALLE, Bertram F. Of Windmills and Straw Men: Folk Assumptions of mind and action. In: POCKETT, Susan (org.). Does Conciousness Cause Behavior? Cambridge: MIT press, 2000.

MARAT, Jean-Paul. Plano de legislação criminal. Tradução de João Ibaixe Jr. São Paulo: Quartier Latin, 2008.

MARENBON, John (org.). The Oxford handbook of medieval philosophy. Nova Iorque: Oxford University Press, 2012.

MARGENAU, Henry. Quantum mechanics, free will, and determinism. In: The Journal of Philosophy, v. 64, n. 21, p. 714-725, 1967.

MARQUES, Edgar. Wittgenstein e o tractatus. Rio de Janeiro: Jorge Zahar Editor, 2005.

MARQUES, José Frederico. Tratado de direito penal. Campinas: Bookseller, 1997.

MAURACH, Reinhart. Tratado de Derecho penal. Tradução de Juan Córdoba Ronda, Barcelona: Ariel, 1962.

MELE, Alfred. R. Free Will: Theories, Analysus, and Data. In: POCKETT, Susan (org.). Does Conciousness Cause Behavior? Cambridge: MIT press, 2000.

MERKEL, Grischa. El juego lingüístico de la culpabilidad. In: DEMETRIO CRESPO, Eduardo (org.). Neurociencias y derecho penal: Nuevas perspectivas en el ámbito de la culpabilidad y tratamiento jurídico-penal de la peligrosidad. Madri: Edisofer, 2013.

MERKEL, Reinhard. Nuevas intervenciones en el cerebro. Mejora de la condición mental humana y límites del Derecho Penal. In: DEMETRIO CRESPO, Eduardo (org.). Neurociencias y derecho penal: Nuevas perspectivas en el ámbito de la culpabilidad y tratamiento jurídicopenal de la peligrosidad. Madri: Edisofer, 2013.

MERTON, Robert K. Sociologia: teoria e estrutura. Tradução de Miguel Maillet. São Paulo: Mestre Jou, 1970.

MEZGER, Edmund, Derecho penal - Parte General. Tradução de Conrado A. Finzi. Buenos Aires: Bibliográfica, 1955.

Tratado de Derecho Penal. Tradução de José Arturo Rodriguez Muñoz. Madrid: Editorial Revista de Derecho Privado, 1955.

MIGUENS, Sofia. Filosofia da linguagem. Porto: Universidade do Porto, 2007. 
MIKOSZ, José Eliézer. Livre-arbítrio: Decisões (im)possíveis aos indivíduos diante das limitações da condição humana. In: Cadernos de pesquisa interdisciplinar em ciências humanas, $n^{\circ} 87$, Florianópolis, dezembro de 2007.

MIR PUIG, Santiago. Derecho Penal: Parte General. Barcelona: Reppertor, 2011.

MONTEIRO, Bárbara Viviana Moreira. Livre-arbítrio e determinismo na ação humana. Dissertação de mestrado em Letras. Faculdade de Letras da Universidade do Porto, Porto, 2014.

MONTESQUIEU. Do espírito das leis. Tradução de Jean Melville, São Paulo: Martin Claret, 2007.

MORENO, C.; FISCHER, F. M.; MENNA-BARRETO, L. Aplicações da cronobiologia. In: MARQUES, N.; MENNA-BARRETO, L. (Org.). Cronobiologia: princípios e aplicações. São Paulo: EDUSP, 1997.

MOURA, Grégore Moreira de. Do Princípio da co-culpabilidade. Rio de Janeiro: Editora Impetus, 2006.

MOUTINHO, Luiz Damon. Sartre: passagem da psicologia à fenomenologia. In: Revista Discurso, São Paulo, vol. 23, 1994, pp.109-148.

MUÑOZ CONDE, Francisco. Derecho penal y control social. Jerez: Fundación Universitária de Jerez, 1985.

Introducción al derecho penal. Barcelona: Bosch, 1975.

Edmund Mezger y el derecho penal de sua tiempo: Estudíons sobre el derecho penal en el nacional socialismo. Valência: Tirant lo Blanch, 2003.

NAGEL, Thomas. Freedom. In: WATSON, Gary (org.). Free Will. Nova Iorque: Oxford University Press, 2003.

NÁQUIRA RIVEROS, Jaime. Constitución Política y fundamento material del principio de culpabilidad. In: Revista Chilena de Derecho, p. 189-200, 1995.

NATALI, Carlo. Por que Aristóteles escreveu o livro III da EN? In: Analytica. Revista de Filosofia, Rio de Janeiro, v. 8, n. 2, p. 47-75, 2013.

NEVES, Luiz Gabriel Batista. A liberdade de atuação como fundamento da culpabilidade. Dissertação de mestrado em Direito. Faculdade de Direito da Universidade Federal da Bahia, Salvador, 2016.

NEVES, Marcelo. Entre Têmis e Leviatã: uma relação difícil. O Estado Democrático de Direito a partir e além de Luhmann e Habermas. São Paulo: Martins Fontes, 2006. 
NIETZSCHE. Friedrich. O crepúsculo dos ídolos: ou como se filosofa com o martelo. Tradução de Paulo César de Souza. São Paulo: Companhia das letras, 2006.

. Humano, demasiado humano II. Tradução de Paulo César de Souza. São Paulo: Companhia das letras, 2008.

NINO, Carlos Santiago. La huida frente a las penas. In: Programma, n. 1, p. 17-40, 2005.

NOUDELMANN, François (org.). Dictionnaire Sartre. Paris: Honoré Champion, 2004.

NOVAES, Adauto. O risco da ilusão. In: NOVAES, Adauto (org.). O avesso da liberdade. São Paulo: Companhia das letras, 2002.

NUNES, Leandro Gornicki. Culpabilidade e Exculpação. Rio de Janeiro: Lumen Juris, 2012.

ORTEGA Y GASSET, José. Meditações do Quixote. Tradução de Gilberto de Mello Kujawski. São Paulo: Iberoamericana, 1967.

PABlOS DE MOLINA, Antonio Garcia. Tratado de Criminologia. Valencia: Tirant lo blanch, 1999.

PALADINO, Carolina Freitas. A corresponsabilização penal estatal: réquiem ou remição das funções das penas privativas de liberdade. In: Revista da seção judiciária do Rio de Janeiro, vol. 18, n. 30, pp. 207-232, 2011.

PASSINGHAM, Richard. E.; LAU, Hakwan C. Free Choice and Human Brain. In: POCKETT, Susan (org.). Does Conciousness Cause Behavior? Cambridge: MIT press, 2000.

PEARSON, Geoff. A sociologia do desajuste e a política de socialização. In: TAYLOR, lan; WALTON, Paul; YOUNG, Jock (Org.). Criminologia crítica. Tradução Juarez Cirino dos Santos e Sérgio Tancredo. Rio de Janeiro: Graal, pp.177-202, 1980.

PÉREZ CEPEDA, Ana Isabel. La peligrosidad en la teoría del delito. Exercício de Cátedra em Direito penal da Universidade de Salamanca, Salamanca, 2016.

La seguridad como fundamento de la deriva del derecho penal postmoderno. Madri: Iustel, 2007.

PÉREZ MANZANO, Mercedez. El tiempo de la consciencia y la libertad de decisión: bases para una reflexión sobre Neurociencia y responsabilidad penal In: DEMETRIO CRESPO, Eduardo (org.). Neurociencias y derecho penal: Nuevas perspectivas en el ámbito de la culpabilidad y tratamiento jurídico-penal de la peligrosidad. Madri: Edisofer, 2013.

PINATEL, Jean. La criminologie. Paris: Spes, 1960.

PINKER, Steve. Como a mente funciona. $3^{a}$ ed. Tradução de Laura Teixeira Motta. São Paulo: Companhia das Letras, 2012. 
PIRES, Alvaro. A racionalidade penal moderna, o público e os direitos humanos. In: Novos Estudos - CEBRAP, n. 68, pp. 39-60, março 2004.

PIRES, Alvaro; DIGNEFFE, Françoise. Vers un paradigme des inter-relations sociales? In: Nouvelles connaissances et nouvelles questions en criminologie, Montréal, vol. 25, no 2, pp 13-47, 1992.

POPPER, Karl. Sobre nubes y relojes aproximación al problema de la racionalidad y libertad del hombre, In: Conocimiento objetivo. Tecnos, Madrid, 1982.

PRADO, Luiz Regis. Bem jurídico-penal e Constituição. São Paulo: Revista dos Tribunais, 2013.

PRINZ, Wolfgang. Free Will as a Social Institution. In: POCKETT, Susan (org.). Does Conciousness Cause Behavior? Cambridge: MIT press, 2000.

PUTNAM, Hilary. Mind, language and reality. Cambridge: Cambridge University Press, 2003.

The many faces or realism. Chicago: La Salle, 1995.

QUEIROZ, Paulo de Souza. Do caráter subsidiário do direito penal. Belo Horizonte: Del Rey, 2008.

QUINNEY, Richard. O controle do crime na sociedade capitalista: uma filosofia crítica da ordem legal. Tradução de Juarez Cirino dos Santos. In: TAYLOR, lan; WALTON, Paul; YOUNG, Jock (Orgs.). Criminologia crítica. Rio de Janeiro: Graal, pp. 221-248, 1980.

QUINTERO OLIVARES, Gonzalo. Monismo y dualismo. In: DEMETRIO CRESPO, Eduardo (org.). Neurociencias y derecho penal: Nuevas perspectivas en el ámbito de la culpabilidad y tratamiento jurídico-penal de la peligrosidad. Madri: Edisofer, 2013.

RAMOS, Pedro Nogueira. Torturem os Números que Eles Confessam. Coimbra: Almedina, 2013.

RAMOS VÁZQUEZ, José Antonio. La pregunta por la libertad de acción (y una respuesta desde la filosofía del lenguaje). In: DEMETRIO CRESPO, Eduardo (org.). Neurociencias y derecho penal: Nuevas perspectivas en el ámbito de la culpabilidad y tratamiento jurídicopenal de la peligrosidad. Madri: Edisofer, 2013.

RAWLS, John. A Theory of Justice. Cambridge-Mass: Harvard University Press, 1971.

REBÊLO, José Henrique Guaracy. Princípio da insignificância: interpretação jurisprudencial. Belo Horizonte: Del Rey, 2000.

REIK, Theodor. Myth and Guilt: The Crime and Punishment of Mankind. Nova Iorque: George Braziller, 1957. 
REIWALD, Paul. Society and its criminals. Nova Iorque: International Universities Press, 1950.

RIBEIRO, Arthur Davis Floriano. Vontade livre e desvalor da ação no direito penal brasileiro. Dissertação de mestrado em Direito. São Paulo: Pontíficia Universidade de São Paulo, 2011.

RICOEUR, Paul. O Discurso da Ação. Tradução de Artur Morão. Lisboa-Portugal: Edições 70, 1988.

ROBINSON, Joan. Liberdade e necessidade. Tradução de Elizabeth Machado de Oliveira. São Paulo: Abril Cultural, 1980 (Coleção Os pensadores).

ROCHA, Fábio Libório. O conceito de servo arbítrio em Schopenhauer. Dissertação de mestrado em Filosofia. Universidade Gama Filho. Rio de Janeiro, 2000.

RODRIGUEZ, Víctor Gabriel. Livre Arbítrio e Direito penal: Revisão frente aos aportes da neurocência e à evolução dogmática. Tese de Livre-docência em Direito, Faculdade de Direito de Ribeirão Preto da Universidade de São Paulo, Ribeirão Preto, 2014.

ROMEO CASABONA, Carlos $\mathrm{M}^{\mathrm{a}}$. Presupuestos biológicos y culpabilidad penal. In: DEMETRIO CRESPO, Eduardo (org.). Neurociencias y derecho penal: Nuevas perspectivas en el ámbito de la culpabilidad y tratamiento jurídico-penal de la peligrosidad. Madri: Edisofer, 2013.

ROSKIES, Adina L. Why Libet's studies don't pose a threat to free will. In: NADEL, Lynn; SINNOTT-ARMSTRONG, Walter (orgs.). Concious will and responsability. Oxford: Oxford University Press, 2011.

ROSS, Peter W. Empirical Constraints on the Problem of Free Will. In: POCKETT, Susan (org.). Does Conciousness Cause Behavior? Cambridge: MIT press, 2000.

ROXIN, Claus. ROXIN, Claus. Culpabilidad y exclusión de la culpabilidad en el derecho penal. In: Revista peruana de Doctrina y Jurisprudencia penales, Lima, ${ }^{\circ} 1,2000$.

Culpabilidad y prevención en Derecho penal. Tradução de Francisco Muñoz Conde. Madrid: Reus, 1981.

Civitas, 1997.

Derecho penal: parte general. Tradução de Diego Manuel Luzón Peña, Madrid:

Estudos de Direito penal. Tradução de Luís Greco. Rio de Janeiro: Renovar, 2008.

Política criminal y sistema del derecho penal. Tradução de Francisco Muñoz Conde. Barcelona: Bosch, 1972.

ROWE, W. L. Two concepts of freedom. In: O'CONNOR, T. (ed.), Agents, cases and events. Essays on indeterminism and free will. Oxford: Oxford University Press, 1995. 
RUBIA, Francisco José. El fantasma de la libertad. Datos de la revolución neurocientífica, Barcelona: Crítica, 2009.

Neurociencia y libertad. In: DEMETRIO CRESPO, Eduardo (org.). Neurociencias y derecho penal: Nuevas perspectivas en el ámbito de la culpabilidad y tratamiento jurídicopenal de la peligrosidad. Madri: Edisofer, 2013.

RUSCHE, Georg; KIRCHHEIMER, Otto. Punição e estrutura social. Tradução de Gizlene Neder. Rio de Janeiro: Revan, 2004.

SÁ, Alvino Augusto de. Concepção de crime como expressão de uma história de conflitos: implicações na reintegração social dos condenados à pena privativa de liberdade. In: Revista da ESMESC, n. 11, p. 169-178, 2001.

Criminologia clínica e execução penal. São Paulo: RT, 2011.

SACRINI, Marcus. Sartre entre reflexão fenomenológica e reflexão pura. In: Revista Philósophos. Goiania, v. 17, p. 109-126, 2012.

SÁNCHEZ-ANDRÉS, Juan Vicente. El espacio de la responsabilidade em el determinismo. In: DEMETRIO CRESPO, Eduardo (org.). Neurociencias y derecho penal: Nuevas perspectivas en el ámbito de la culpabilidad y tratamiento jurídico-penal de la peligrosidad. Madri: Edisofer, 2013.

SÁNCHEZ-LÁZARO, Fernando Guanarteme. Operando con el principio de culpabilidad. In: DEMETRIO CRESPO, Eduardo (org.). Neurociencias y derecho penal: Nuevas perspectivas en el ámbito de la culpabilidad y tratamiento jurídico-penal de la peligrosidad. Madri: Edisofer, 2013.

SANZ MORÁN, Ángel. Algunas consideraciones sobre culpabilidad y pena. In: Díez Ripollés, José et al (orgs.). La Ciencia del Derecho Penal ante el nuevo siglo. Libro Homenaje al Profesor Doctor Don José Cerezo Mir. Madrid: Tecnos, 2003.

SANTOS, Carlos Alberto Gomes dos. Determinismo e liberdade: uma conciliação possível. In: Ciência \& Saúde Coletiva. Rio de Janeiro. v. 10, n. 3, p. 537-539, 2005.

SANTOS, Juarez Cirino dos. A Criminologia radical. Rio de Janeiro: Forense, 1981.

A moderna teoria do fato punível. Rio de Janeiro: Freitas Bastos, 2002.

Direito penal: parte geral. Florianópolis: Conceito Editorial, 2012.

SANTOS FILHO. Agenor José dos. O princípio da co-culpabilidade na perspectiva dos direitos fundamentais sociais. Dissertação de mestrado em Direito, Univem, Marília, 2012.

SARLET, Ingo Wolfgang. Dignidade da pessoa humana e direitos fundamentais na Constituição Federal de 1988. Porto Alegre: Livraria do Advogado, 2001. 
. A eficácia dos Direitos Fundamentais. Porto Alegre: Livraria do Advogado, 2004.

SARTRE, Jean-Paul. A transcendência do ego: esboço de uma descrição fenomenológica. Tradução de João Batista Kreuch. Petrópolis: Vozes, 2013.

. L'existencialisme est un humanisme. Paris: Nagel, 1946.

O ser e o nada. Tradução de Paulo Perdigão. Petrópolis: Vozes, 2001.

Une idée fondamentale de la phénoménologie de Husserl: l'intentionnalité. In: La transcendance de l'Ego et autres textes phénoménologiques. Paris: Vrin, 2003.

SAVATER, Fernando. El valor de elegir. Barcelona: Ariel, 2003.

Ética para amador. Barcelona: Ariel, 1991.

SCHELER, Max. Metafísica de la libertad. Tradução de Walter Liebling. Buenos Aires: Editorial Nova, 1970.

SCHMID, Joseph. Anomie in the development context. In: ATTESLANDER, P. et al. (Org.). Comparative anomie research: hidden barriers - hidden potential for social development. Sidney: Ashgate, 1999.

SCHOPENHAUER, Arthur. O livre-arbítrio. Tradução de Lohengrin de Oliveira. Rio de Janeiro: Edições de Ouro, 1967.

SCHÜNEMANN, Bernd. La función de la delimitación de injusto y culpabilidad. Tradução de Carlos J. Suárez González. In: SCHÜNEMANN, Bernd; DIAS, Jorge Figueiredo (org.). Fundamentos de un sistema europeo del Derecho Penal. Libro Homenaje a Claus Roxin. Barcelona: J. M. Bosch, 1995.

. La función del principio de culpabilidad en el Derecho Penal preventivo. Tradução de Jesús-María Silva Sánchez. In: SILVA SÁNCHEZ, Jesús-María; SCHÜNEMANN, Bernd (org.). El sistema moderno del Derecho Penal: cuestiones fundamentales. Madrid: Tecnos, 1991.

La política criminal y el sistema de derecho penal. Tradução de Margarita Martfnez de Escamillla. In: Anuário de Derecho Penal y Ciencias Penales, pp. 693-713, set-dez, 1991.

. Libertad de voluntad y culpabilidad. In: Temas actuales y permanentes del derecho penal después del milenio. Madri: Tecnos, 2002.

Temas actuales y permanentes del Derecho Penal después del milênio. Tradução de Marina Sacher. Madrid: Tecnos, 2002.

SEARLE, John. Freedom and Neurobiology: Reflections on Free Will, Language and Political Power. Nova Iorque: Columbia University Press, 2007. 
Mente, cérebro e ciência. Tradução de Artur Morão. Lisboa: Edições 70, 1987.

. The construction of social reality. Nova Iorque: Simon and Schuster, 1995.

SECRÉTAN, Charles secrétan. La civilisation et la croyance. Paris: Alcan, 1887.

SERRANO-PIEDECASAS, José Ramon. El pensamiento complejo y el Derecho penal. In: DEMETRIO CRESPO, Eduardo (org.), Neurociencias y derecho penal: Nuevas perspectivas en el ámbito de la culpabilidad y tratamiento jurídico-penal de la peligrosidad. Madri: Edisofer, 2013.

SERRANO-PIEDECASAS, J. R.; DEMETRIO CRESPO, Eduardo. Reflexiones sobre filosofía del lenguaje, diversidad cultural, y su influencia en el derecho penal. In: CARBONELL MATEU, J. C. et al. (orgs.), Constitución, Derechos Fundamentales y Sistema penal. Valencia: Tirant lo Blanch, 2009.

SHECAIRA, Sérgio Salomão. A mídia e o direito penal. In: Boletim IBCCRIM. São Paulo, n. 45, p. 16, ago. 1996.

Criminologia. São Paulo: Revista dos Tribunais, 2014.

Mídia e crime. In: SHECAIRA, Sérgio Salomão (org.). Estudos criminais em homenagem a Evandro Lins e Silva (criminalista do século). São Paulo: Método, 2001.

Pena e política criminal. A experiência brasileira. In: SÁ, Alvino Augusto; SHECAIRA, Sérgio Salomão (Org.). Criminologia e os problemas da atualidade. São Paulo: Atlas, 2008, pp. 321-334, p. 325.

SIDMAN, Murray. Coerção e suas implicações. Tradução de Maria Amália Andery e Tereza Maria Sério. Campinas: Livro Pleno, 2009.

SILVA, Katia Cilene da. O problema da liberdade na filosofia de Arthur Schopenhauer. Dissertação de mestrado em Filosofia. Faculdade de Filosofia, Letras e Ciências Humanas da Universidade de São Paulo. São Paulo, 2010.

SILVA, Raíssa Zago Leite da. Labelling Approach: o etiquetamento social relacionado à seletividade do sistema penal e ao ciclo da criminalização. In: Revista Liberdades, p. 101-156, 2015.

SILVA SÁNCHEZ, Jesús-María. La expansión del Derecho penal. Aspectos de la política criminal en las sociedades postindustriales. Madri: Civitas, 2001.

SKINNER, Burrhus Frederic et al. Beyond freedom and dignity. New York: Bantam Books, 1972.

SMART, J. J. C. Free will, Praise and Blame. In: WATSON, Gary (org.). Free Will. Nova Iorque: Oxford University Press, 2003. 
SMITH, Steven. In Defense of Mentalism: A Critical Review of the Philosophy of Mind. In: The Review of Metaphysics, v. 43, n. 1, 1989.

SOBER, Elliott. Core Questions in Philosophy: A Text with Readings. Upper Saddle River: Prentice Hall, 2008.

SPINOZA, Baruch. Ética. $3^{\text {a }}$ ed. Tradução de Tomaz Tadeu. Belo Horizonte: Autêntica, 2010.

SUTHERLAND, Edwin Hardin; GEIS, Gilbert; GOFF, Colin. White collar crime: The uncut version. New Haven: Yale University Press, 1983.

TANGERINO, Davi de Paiva Costa. Apreciação crítica dos fundamentos da culpabilidade a partir da criminologia: contribuições para um direito penal mais ético. Tese de Doutorado em Direito Penal. Faculdade de Direito Universidade de São Paulo, São Paulo, 2009.

TAVARES, Juarez. Critérios de seleção de crimes e cominação de penas. In: Revista Brasileira de Ciências Criminais (RBCCRIM) (RBCCRIM) - número especial de lançamento, pp. 75-87, 1992.

. Culpabilidade: a incongruência dos métodos. In: Revista Brasileira de Ciências Criminais (RBCCRIM), n. 24, pp. 145-156, 1998.

. Culpabilidade e individualização da pena. In: BATISTA, Nilo; NASCIMENTO, André (Orgs.). Cem anos de reprovação: uma contribuição transdisciplinar para a crise daculpabilidade. Rio de Janeiro: Revan, 2011.

La dommatica del reato e il contesto delle relazioni della vita. In: CAVALIERE, Antonio et al. (org.) Política criminale e cultura giuspenalistica. Scritt in Onore di Sergio Moccia. Nápolis: Edizione Scientifiche Italiane, pp. 359-373, 2017.

Teoria do injusto penal. $3^{\text {a }}$ edição. Belo Horizonte: Delrey, 2003.

TELLES JR., Goffredo da Silva. O Direito Quântico. Ensaio sobre o fundamento da ordem jurídica. São Paulo: Juarez de Oliveira, 2006.

THISEN, Graciela Fernandes. O processo penal e a cerimônia degradante. Dissertação de Mestrado em Direito. Pontifícia Universidade Católica - Rio Grande do Sul, Porto Alegre, 2006.

BARRETO, Tobias. Fundamentos do direito de punir. In: Revista dos Tribunais, v. 727, p. 640-650, 1996.

TOMÁS DE AQUINO. Suma de Teología. Tradução de José Martorell Capó. Madri: Biblioteca de autores cristianos, 2001.

URBAN, Wilbur Marshall. Lenguaje y realidad. Tradução de Carlos Villegas e Jorge Portilla. Cidade do México: Fondo de Cultura Economica, 1952. 
VALÉRY, Paul. Essais quasi politiques. In: HYTIER, J. (org.). Oeuvres. Paris: Gallimard, 1957.

Fluctuations sur la liberte. In: Regards sur le monde actuel et autres essais. Paris: Éditions Gallimard, 1945.

VAN INWAGEN, Peter. An essay on free will. Oxford: Clarendon Press, 1983.

VELMANS, Max. Understanding Consciousness. London: Routledge, 2000.

VERGARA, Pedro. Dos motivos determinantes no direito penal. Rio de Janeiro: Direito Applicado, 1937.

VIEIRA NETO, Paulo. Afetos, alienação e liberdade. In: NOVAES, Adauto (org.). O avesso da liberdade. São Paulo: Companhia das letras, 2002.

VIVES ANTÓN, Tomás Salvador. El principio de la culpabilidad. In: Díez Ripollés, José et al (orgs.). La Ciencia del Derecho Penal ante el nuevo siglo. Libro Homenaje al Profesor Doctor Don José Cerezo Mir. Madrid: Tecnos, 2003.

Fundamentos del sistema penal. Valência: Tirant lo Blanch, 2011.

. Neurociencia y determinismo reduccionista: una aproximación crítica. In: DEMETRIO CRESPO, Eduardo (org.). Neurociencias y derecho penal: Nuevas perspectivas en el ámbito de la culpabilidad y tratamiento jurídico-penal de la peligrosidad. Madri: Edisofer, 2013.

VON HIRSCH, Andrew et al. Criminal Deterrence and Sentence Severity: An Analysis of Recent Research. Oxford: Hart Publishing, 1999.

WALLERSTEIN, Immanuel. Análise dos sistemas mundiais. In: GIDDENS, Anthony; TURNER, Jonathan (orgs.). Teoria social hoje. Tradução de Gilson César Cardoso de Sousa. Sao Paulo: Editora UNESP, 1999.

WATSON, Gary. Free agency. In: WATSON, Gary (org.). Free Will. Nova Iorque: Oxford University Press, 2003.

WATSON, John B. Behaviorism. Chicago: University of Chicago Press, 1930.

WEIL, Eric. Logique de la philosophie. Paris: Vrin, 2000.

WELZEL, Hans. Derecho penal aleman: parte general. Tradução de Juan Bustos Ramírez e Sergio Yáñez Pérez. Santiago: Jurídica de Chile, 1993.

O novo sistema jurídico-penal: uma introdução à doutrina da ação finalista. Tradução de Luiz Regis Prado. São Paulo: Revista dos Tribunais, 2011. 
Reflexiones sobre el "libre albedrío". Tradução de José Cerezo Mir. In: Anuario de Derecho Penal y Ciencias Penales. vol. 26, pp. 221-231, 1973.

WIGGINS, David. Towards a Reasonable Libertarianism. In: WATSON, Gary (org.). Free Will. Nova Iorque: Oxford University Press, 2003.

WINNICOTT, Donald W. Privação e delinquência. $4^{\mathrm{a}}$ ed. Tradução de Álvaro Cabral. São Paulo: Martins Fontes, 2005.

WITTGENSTEIN, Ludwig. Investigações Filosóficas. Tradução de José Carlos Bruni. São Paulo: Nova Cultural, 1999.

Press, 1990.

Last writings on the philosophy of psychology. Chicago: The University of Chicago On certainty. Anscombe: Malden, Ma Blackwell, 2010.

1998.

Philosophical Remarks. Tradução de Raymond Hargreaves. Oxford: Blackwell,

Tractatus Logico-philosophicus. Tradução de José Arthur Giannotti. São Paulo: Cia Editora Nacional, 1968.

WOLFF, Francis. A invenção materialista da liberdade. In: NOVAES, Adauto (org.). O avesso da liberdade. São Paulo: Companhia das letras, 2002.

WRIGHT, Robert. The Moral Animal. Nova Iorque: Pantheon Books, 1994.

YAROCHEWSKY, Leonardo Isaac. Da exigibilidade de conduta diversa. Belo Horizonte: Del Rey, 2000.

YOUNG, Jock. The Exclusive Society: Social Exclusion, Crime and Difference in Late Modernity. Londres: Thousand Oaks, 1999.

ZAFFARONI, Eugenio Raúl. Culpabilidade por vulnerabilidade. Tradução de Tradução: Fernanda Freixinho e Daniel Raizman. In: Discursos sediciosos, n. 14, Rio de Janeiro: Revan, pp. 31-48, 2004.

Em busca das penas perdidas: a perda da legitimidade no sistema penal. Rio de Janeiro: Revan, 1996.

La co-culpabilidad em la legislación comparada: política criminal latinoamericana. Buenos Aires: Hamurabi, 1981.

Política criminal latinoamericana: perspectivas - disyuntivas. Buenos Aires: Editorial Hammurabi, 1982. 
ZAFFARONI, Eugenio Raúl; BATISTA, Nilo. Direito penal brasileiro. Volume I. Rio de Janeiro: Revan, 2006.

ZAFFARONI, Eugenio Raúl; PIERANGELI, José Henrique. Manual de direito penal brasileiro, volume I: parte geral. São Paulo: Revista dos Tribunais, 2008.

ZAFFARONI, Eugenio Raúl; ALAGIA, Alejandro; SLOKAR, Alejandro. Manual de Derecho Penal: Parte General. Buenos Aires: Ediar, 2006.

ZAGZEBSKI, Linda Trinkaus. The Dilemma of Freedom and Foreknowledge. Oxford: Oxford University Press, 1991.

ZANOTELLO, Marina. O princípio da coculpabilidade no estado democrático de direito. Dissertação de mestrado em Direito. Faculdade de Direito da Universidade de São Paulo, São Paulo, 2013.

ZINGANO, Marco. Sobre a Metafísica de Aristóteles. São Paulo: Odysseus, 2005. 